\title{
Takım oluşturma ve takım devamlılığı arasındaki ilişkide takım performansının aracılık rolü
}

\section{The mediating role of team performance in the relationship between team building and team viability}

\author{
Yunus Emre Taşgit ${ }^{1}$ iD \\ Merve Bayraktar² \\ Nisa Kaplan ${ }^{3}$ \\ Mehmet Öney ${ }^{4}$ (D)
}

1 Doç. Dr., Düzce Üniversitesi, İşletme Fakültesi, İşletme Bölümü, Düzce, Türkiye, yunusemretasgit@duzce.edu.tr

ORCID: 0000-0003-2176-1733

2 Doktora Öğrencisi, Düzce Üniversitesi, Sosyal Bilimler Enstitüsü, İşletme A.B.D., Düzce, Türkiye, mrvaksit@gmail.com

\section{ORCID: 0000-0002-3936-5635}

${ }^{3}$ Doktora Öğrencisi, Düzce Üniversitesi, Sosyal Bilimler Enstitüsü, İssletme A.B.D. Düzce, Türkiye,nisakaplann@hotmail.com

ORCID: 0000-0001-5793-2624

${ }^{4}$ Doktora Öğrencisi, Düzce Üniversitesi, Sosyal Bilimler Enstitüsü, İşletme A.B.D., Düzce,Türkiye, mehmetoney81@gmail.com

ORCID: 0000-0002-4513-2870

\section{Sorumlu Yazar/Corresponding Author:}

Yunus Emre Taşgit,

Düzce Üniversitesi, Düzce, Türkiye, yunusemretasgit@duzce.edu.tr

Başvuru/Submitted: 25/04/2021

Revizyon/Revised: 2/06/2021

Kabul/Accepted: 26/06/2021

Yayın/Online Published: 25/09/2021

Citation: Taşgit, Y.E., \& Bayraktar, M., \& Kaplan, N., \& Öney, M., Takım oluşturma ve takım devamlılığı arasındaki ilişkide takım performansının aracılık rolü, bmij (2021) 9 (3): 922-942, doi: https://doi.org/10.15295/bmij.v9i3.1848

Öz

$\mathrm{Bu}$ araştırma, takım oluşturma, takım performansı ve takım devamlılığı arasındaki ilișkileri incelemeyi amaçlamaktadır. Bu kapsamda takım performansının aracılık rolünün tespit edilmesi araştırmanın temel problemini oluşturmaktadır. Araştırmada ilişkisel tarama modeli tercih edilmiştir. Veriler, anket tekniği ile toplanmıştır. Toplamda 375 katılımcıdan elde edilen veriler üzerinden araștırma modeli test edilmiștir. Verilerin analizinde SPSS 21.0 ve LISREL 8.72 programları kullanılmıştır. Analiz sonucunda takım oluşumu ve takım devamlılığı ile ilgili tek boyutlu, takım performansı ile ilgili iki boyutlu (sosyalleşme, dayanışma) bir yapıya ulașılmıștır. Takım yapısı, takım performansı ve takım devamlılı̆̆ arasında yüksek düzeyde pozitif yönlü anlamlı ilişkiler tespit edilmiştir. Takım oluşturma ve devamlılık arasındaki ilişkide performans anlamlı düzeyde kısmi aracılık etkisine sahipken dayanışma performansının sosyalleşme performansına nispeten daha önemli bir kısmi aracılık rolüne sahip olduğu belirlenmiştir.

Anahtar Kelimeler: Takım Oluşturma, Takım Devamlılığı, Takım Performansı, Sosyalleşme Performans, Dayanışma Performansı

JEL Kodlar1: M12, M51, M54

\begin{abstract}
This research aims to examine the relationships between team building, team performance and team viability. In this context, determining the mediating role of team performance constitutes the main problem of the study. In the research, the relational scanning model was preferred. The data were collected by questionnaire technique. The research model was tested on the data obtained from 375 participants in total. SPSS 21.0 and LISREL 8.72 programs were used to analyse the data. As a result of the analysis, a one-dimensional structure related to team formation and team viability and a twodimensional (sociability, solidarity) related to team performance was reached. High levels of positive and significant relationships were found between team structure, team performance and team viability. It has been determined that team performance has a significant partial mediating effect in the relationship between team building and team viability, and solidarity performance has a relatively important partial mediating role in sociability performance.
\end{abstract}

Keywords: Team Building, Team Viability, Team Performance, Sociability Performance, Solidarity Performance

JEL Codes: M12, M51, M54

(C) 2021 The Author(s)

Bu makale, araștırma ve yayın etiğine uygun hazırlanmış ve iThenticate ile intihal taramasından geçirilmiştir. This article was prepared in line with research and publication ethics and scanned for plagiarism by using iThenticate. 


\section{Extended Abstract}

\section{The mediating role of team performance in the relationship between team building and team viability}

\section{Purpose and problematic of the research}

This research examines the relationships between team building, team performance, and team viability. In this context, answers to the following questions were sought: Does team building affect team performance? Does team building affect team viability? Does team performance affect team viability? Finally, does team performance have a mediating effect on the relationship between team building and team viability?

\section{Literature}

In the literature, processes related to team-based organizations are discussed from different perspectives. When these studies are examined, it is seen that the issue is mainly discussed within the framework of determining the effect of team building on team performance. In this study, the mediating role of team performance in the relationship between team building and team continuity will be examined to provide a complementary contribution to ensuring subject integrity. As a result of the literature review, the fact that no study is carried out in the same model includes the opportunity to move the research to a reference position for future studies. The research is built on the basic assumption that "teams that do not perform successfully will not be able to continue".

\section{Design and method}

In the research, the relational scanning model was preferred among quantitative methods. The data were collected by questionnaire technique. The research model was tested on the data obtained from 375 participants in total. SPSS 21.0 and LISREL 8.72 programs were used to analyze the data. For the team building scale, the scale developed by Aga et al. (2016) was used. This scale; includes goal setting, interpersonal relationships, role setting and problem-solving (Klein et al., 2009; Salas et al., 1999). The team performance scale was examined in 2 dimensions, sociability performance and solidarity performance, inspired by the studies of Goffee and Jones (1998), to evaluate the issue more holistically while benefiting from the perspectives of currently available scales. Another study variable, the scales developed by Aubé and Rousseau (2005) and Cooperstein (2017), were used for team viability.

The research model was created based on the literature review and the researchers' observations on the management of the teams. Details related to the appearance of the model and the relationships between variables are shown in Figure 1.

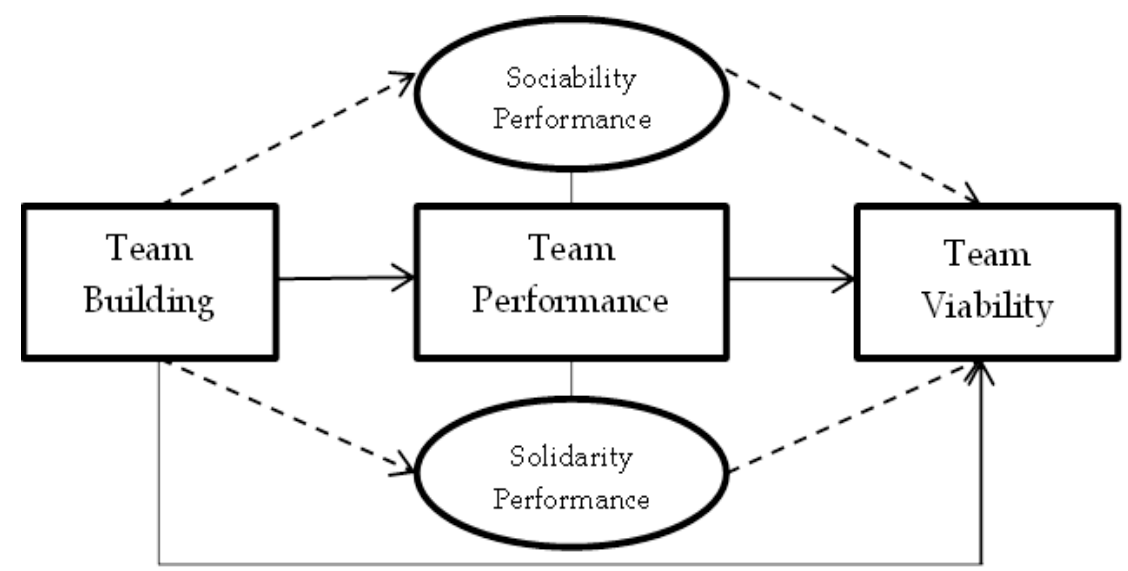

Figure 1: Research Model

\section{Findings and discussion}

As a result of the analysis, high levels of positive and significant relationships were found between team building, team performance and team viability. Furthermore, in the relationship between team building and team viability, while team performance has a significant partial mediating effect, it has been determined that solidarity performance has a relatively important partial mediating role in sociability performance. In line with this information, the following research hypotheses have been accepted.

- "H1: Team building has a positive effect on team continuity".

- "H2: Team performance has a positive effect on team continuity".

- "H3: Team building has a positive effect on team performance".

- "H4: Team performance has a mediating effect in the relationship between team building and team viability."

- "H5a,b: In the relationship between team building and team continuity (a) Solidarity Performance has a relatively more important mediating effect on (b) Sociability Performance."

\section{Results of the article}

According to the discussions on the findings so far, it does not seem possible for the teams formed to continue their lives without displaying result-oriented performance. On the other hand, although it is low compared to the solidarity performance, the mediating role of socialization performance is also significant. Therefore, it can be argued that team members' social relationship forms and levels are also crucial for team viability. In this context, considering only the solidarity performance as team performance will contribute significantly to the result-oriented formulations and may lead to the weakness of social aspects such as sincerity, loyalty and loyalty within the team. Again, giving importance to social performance only increases the sincerity and loyalty within the team, and it may lead to the occurrence of some abuse situations in result-oriented work. Therefore, both types of performance should be considered by managers for team continuity. 


\section{Giriş}

Küresel rekabet ortamında piyasa şartlarına hızla uyabilen esnek organizasyon yapısı oluşturmak, stratejik anlamda büyük önem kazanmıştır (Hitt, Keats ve DeMarie, 1998: 2). Öyle ki iş dünyasında yaşanan gelişmeler esnek şekilde örgütlenmeyi başarının etkili bir formülü olarak sunduğu için mekanistik organizasyon yapılarından organik organizasyon yapılarına geçişi neredeyse zorunlu hale getirmiştir (Jewczyn, 2010: 1-2). Organik ve esnek örgütlenmenin en karakteristik türlerinden biri ise takım çalışmasını bir örgüt kültürü haline getirmiş takım temelli organizasyonlardır (Galbraith, Lawler ve Dimon, 2007: 191). Bu noktada işletmelerin, bireysel yetenekleri etkin şekilde bir araya getirerek takım çalışmalarını doğru şekilde yönetmesi, amaçlarını gerçekleştirme noktasında oldukça kritiktir (Jackson, Chuang, Harden, ve Jiang, 2006: 27). Takımlar artık her türlü işletmede yer almaya başlamıştır (Cohen ve Bailey, 1997: 242) ve bir işletmenin ölçeği ne olursa olsun temel performans biriminin, takımlar olması gerektiği anlayışı giderek yaygınlaşmaktadır (Zigon, 1999: 36). İşletmeler gerek proje odaklı gerekse mevcut işleyiş sürecinde takım oluşturarak hedef ve amaçlarına etkin bir şekilde ulaşmaya çalışmaktadır (Dyer, 2015: 1). Organizasyonların takım oluşturma sürecine yönelik büyük miktarda emek harcadığı düşünüldüğünde bu yaklaşımın başarılı bir şekilde yönetilmesi gereklidir. Bu noktada takım oluşturmanın etkinliğini ve faydalarını, işletmeler açısından hedeflere ulaşmayı kolaylaştıran doğru bir seçim olup olmadığını saptamak önemlidir (Klein, Diaz Granados, Salas, Le, Burke, Lyons, ve Goodwin, 2009: 182-183).

Literatürde takım temelli organizasyonlara ilişkin süreçler, farklı bakış açılarıyla ele alınmaktadır. Bu araştırmalar incelendiğinde, konunun daha çok takım oluşturmanın takım performansı üzerindeki etkisini belirleme çerçevesinde tartışıldığı görülmektedir (Salas, Rozell, Mullen, ve Driskell, 1999; Ciasullo, Cosimato, Gaeta ve Palumbo, 2017). Konu bütünlüğünün sağlanmasına tamamlayıcı katkı niteliğinde bu araştırmada takım oluşturma ile takım devamlılığı arasındaki ilişkide takım performansının aracılık rolü incelenecektir. Yapılan literatür incelemesi sonucunda aynı modelde gerçekleştirilmiş bir çalışmaya rastlanılmamış olması araştırmayı sonraki çalışmalar için referans konumuna taşıma imkanını içermektedir. Araştırma "başarılı performans sergilemeyen takımların devam etmelerinin genelde mümkün olmayacağı" temel varsayımı üzerine kurgulanmıştır ve takım oluşturma ile takım devamlılığı arasındaki ilişkide takım performansının aracılık rolünün tespit etmeyi amaçlamaktadır. Bu kapsamda takım oluşturmanın takım performansı üzerinde etkisi var mıdır? Takım oluşturmanın takım devamlılığı üzerinde etkisi var mıdır? ve Takım performansının takım devamlılığı üzerinde etkisi var mıdır? ve Takım Performansı, takım oluşturma ve takım devamlılığı arasındaki ilişkide aracılık etkisine sahip midir? sorularına cevap aranmıştır.

\section{Literatür taraması}

\section{Takım oluşturma}

Takım oluşturma, paylaşılan hedeflere ulaşmanın yolunu açan, bireysel, grup ve örgütsel ihtiyaçlar arasında bir denge oluşturmakla ilgilidir (Ciasullo vd., 2007: 334). Örgütsel görevlerin ve sorumlulukların atanma şeklinin derinlemesine bir analizinden oluşur ve ekip süreçlerinin kapsamlı bir incelemesini içermektedir (Klein vd, 2009: 181-182). Dyer (2015: 1) takım oluşturmayı, organizasyonların hedeflerine ulaşmak için birlikte çalışması gereken kişilerin, iş birliği çabalarını geliştirmek için tasarlanmış planlı, sistematik bir süreç olarak tanımlamıştır. Takım oluşturmanın, ekip üyeleri arasındaki iletişimi geliştirmek, üretkenliği ve yaratıcılığ artırmak, daha iyi çalışma politikaları ve prosedürleri elde etmek, takım üyelerini hedeflere ulaşmaları için motive etmek, açı çalışma hedefleri ve bir iş birliği ve iş birliğine dayalı problem çözme ortamı sağlamak gibi başlıca amaçları vardır (Fapohunda, 2013: 4). Bununla birlikte takım oluşturma faaliyetlerinin birincil amacı, çalışma ekiplerinin etkinliğini artırmaktır (Buller ve Bell, 1986: 305-306). Takım etkinliği birlikte çalışmayı, disiplinli olmayı, birbiriyle iletişim kurmayı ve sosyalleşmeyi içerir (Altaftazani, Rahayu ve Kelana, 2020: 192). Svyantek, Goodman, Benz, ve Gard (1999: 278) yönetim kademesinin, sürenin, örgütsel desteğin ve organizasyon özelliklerinin takım oluşturmanın başarısı üzerinde etkili olduğunu belirtmiştir. Yine takım oluşturma müdahalelerinin tutum ve algı üzerinde performanstan daha güçlü bir etkisi olduğu düşünülmektedir (Tannenbaum, Beard, ve Salas, 1992: 142). Aynı şekilde Klein vd. (2009: 194), takım oluşturmanın karşılıklı güven ve iletişimi geliştirmesi gibi duygusal sonuçlar üzerinde daha etkili olabileceğini belirtmişlerdir. Son dönemde yapılan çalışmalar takım oluşturma ile takım performansı arasında olumlu ilişkiler olduğu yönündedir (Aga, Noorderhaven, ve Vallejo, 2016: 812; Bartlett, Probber, ve Mohammed 1999: 307-308). Örneğin De Meuse ve Liebowitz'in (1981: 369) takım oluşturma ile takım performansı arasındaki ilişkiyi inceleyen meta analizi çalışmasında, incelediği makalelerin \%80'inde (29 makale) pozitif etkiye rastladığ (1986: 323-326) çalışmalarında, takım oluşturma bileşenlerinden hedef belirlemenin takım performansı ve üretkenlik üzerinde kısmen etkili olduğunu belirlemişlerdir. Benzer şekilde takım oluşturma 
boyutlarından rol belirlemenin takım performansı üzerinde etkisi olduğunu ilişkin (Klein vd., 2009: 194-195; Salas vd., 1999: 321) çalışmalarda bulunmaktadır.

Literatürde takım oluşturma yaklaşımları çeşitlilik göstermektedir. Beer (1976) takım oluşturmanın, hedef belirleme, kişilerarası ilişkiler, rol açılama ve yönetsel sistem süreçlerinden oluştuğunu ifade etmiştir. Diğer yandan Buller (1986: 149) takım oluşturmanın problem çözme süreçlerini içeren bir süreç olduğunu vurgulamıştır. Son zamanlarda yapılan çalışmalarda takım oluşturmanın dört boyut altında ele alındığı görülmektedir. Bunlar; hedef belirleme, kişilerarası ilişkiler, rol tanımlanması ve problem çözme (Klein vd., 2009: 186). Hedef belirleme, bireysel ve takım hedeflerinin belirlenme sürecine takım üyelerinin dahil edilmesini içeren bir yaklaşımdır (Tannenbaum vd., 1992: 119). Bu yaklaşım, ekip üyelerine, bazen alt görevleri tanımlayarak ve zaman çizelgeleri oluşturarak, projenin genel amaçlarını ve hedeflerini açıklığa kavuşturmayı içerir. Bir hedef belirleme sürecine dahil olan takım üyelerinin, bu hedeflere ulaşmanın yollarını belirlemek için eylem planlamasına dahil olmaları beklenir (Aga vd., 2016: 807). Hedefler, çalışanların performansı için motivasyon kaynağıdır (Locke, Shaw, Saari, ve Latham, 1981: 131). Locke ve Latham (2002: 706-707), hedeflerin yönlendirici, enerji verici, sabrı ve eylemleri etkileyen bir bileşen olduğunu ifade eder. Takım üyelerinin hedef belirleme sürecine dahil edilmesi hedeflerin kabulünü artırır ve takım başarısı artış gösterir (Wildmeyer ve Ducharme, 1997: 107). Ayrıca hedef belirleme sürecine dahil olan takım üyelerinin uyumu artmaktadır (Senécal, Loughead, ve Bloom, 2008: 197). Kişilerarası ilişkiler, ekip üyeleri arasındaki ilişkilerin ve çatışmaların açık bir şekilde tartışılmasını teşvik eder ve genellikle gizli gündemleri temizlemeye ve çatışmaları çözmeye yöneliktir (Klein vd., 2009: 187). Kişilerarası ilişkilerde karşılıklı destek ve güven geliştirerek, açık bir iletişimle çatışmaların yüzleşilmesi ve çözülmesiyle daha etkili kararların alındığı bir ortam oluşturulur (Liebowtiz ve De Meuse, 1982: 7). İletişimin artması ve kişilerarası ilişkilerin düzenlenmesi, ekip etkinliğini ve üretkenliğini artırır (Argyris, 1962: 712). Rol belirlenmesi, bireysel rol beklentilerinin, grup normlarının ve ekip üyelerinin paylaşılan sorumluluklarının açıklı̆̆a kavuşturulmasını gerektirir (Klein vd., 2009: 187). Ekip üyeleri arasında ekip içindeki rolleriyle ilgili olarak artan iletişimi vurgular. Rol netleştirme faaliyetleri sonucunda üyeler, kendilerinin ve diğerlerinin ekip içindeki rollerini ve görevlerini daha iyi anlarlar (Salas vd., 1999: 314). Böylece takım üyelerinin rolleriyle ilgili aralarında çıkabilecek sorunların üstesinden gelinir ve takım etkinliği artar (Lacerenza, Marlow, Tannenbaum, ve Salas, 2018: 524). Bir takım üyesinin sorumlulukları hakkındaki bilgisi, diğer takım üyeleri ve takımın genel dinamikleri açısından önemlidir (Eys ve Carron, 2001: 370). Rol belirsizliği, takım üyelerinde duygusal sorunlar oluşturabilir ve verimliliği olumsuz etkiler (Kahn, Wolfe, Quinn, Snoek, ve Rosenthal, 1964: 620). Problem çözme, örgütsel ilişkiler ve hedefler kapsamında görevle ilgili becerileri geliştirmek için takımın görevlerindeki temel sorunların çözülerek başarıyı artırmayı içerir (Buller, 1986: 149). Problem çözme yaklaşımı, takım üyelerinin görevle ilgili sorunları belirlemeleri ve ilgili bilgileri üretmeleri gerektiğini varsayar (Salas vd., 1999: 314). Ayrıca takım üyelerinin problemleri çözmek için eylem planlaması yaptıkları ve eylem planlarını uygulayıp değerlendirdikleri bir yaklaşımdır (Buller ve Bell, 1986: 149-150). Problem çözme yetkinliği, proje ekibinin hedefe ulaşmasına yardımcı olan ekip yetkinliklerinden biridir (Lin, Chen, Hsu, ve Fu,2015: 1693-1694). Takım içerisinde problem çözme yaklaşımı bireylerde sosyalleşme etkileşimi, iletişimi ve grup katılımını olumlu etkiler (Altaftazani vd., 2020: 193).

\section{Takım performansı}

Takımlar, organizasyonel etkinliği arttırmak için örgütlenmiş performans birimleridir (PuentePalacios, Carmo Fernandes Martins, ve Palumbo, 2016: 513) ve tesadüfi olarak bir araya gelen bireyler topluluğuna kıyasla daha verimli ve daha yüksek performansa sahiptirler. Başarılı bir takım için somut performans sonuçlarının takip edilmesi oldukça önemlidir. Hatta "takım" ve "performans" kavramları ayrılamaz kavramlardır (Ergün ve Eyisoy, 2018: 1459).

Takım performansı, bireysel olarak ve bağımsız bir şekilde takım üyelerinin performansı yerine, üyelerden oluşan takımın toplam performansı olarak değerlendirilmektedir (Purtul, 2019: 7). Takım performansı, takım literatüründe girdileri (kaynakları), süreçleri (toplu çaba) ve sonuçları (belirli performans göstergelerini) içeren genelleştirilmiş bir çerçeve olarak ele alınmaktadır (Yammarino, Atwater, ve Spangler, 2004: 179).

Takım performansıyla ilgili öncü çalışmalardan bazıları, takımların etkililiğini takım üyelerinin bilgi alışverişi ve koordinasyon yeteneğine bağlarken (Driskell, 1992: 277) bazı çalışmalarda ise takım performansı, takımın özelliklerini ve süreçlerini kapsayacak şekilde yorumlanmaktadır (Senior ve Swailes, 2004: 319). Bu düşünceyi savunanlara göre süreç ölçümleri, sonuç ölçümlerine nispeten takım işleyişine ilişkin daha gerçekçi bir resim vermektedir. Ayrıca takımın karşılaştı̆̆ı sorunlara ve bunları düzeltme yollarına da ışık tutabilmektedir. 
Literatürde takım performansının ölçümü ile ilgili çeşitli araçlar geliştirilmiştir. Bu ölçüm araçları genel anlamda değerlendirildiğinde, takım performansının daha çok etkililik ve verimlilik kavramları üzerinden ölçümlendiği görülmektedir. Bu değerlendirme her ne kadar doğru olsa da eksik bir değerlendirmedir. Herhangi bir takımın sosyalleşme ve teknik özellikler içerdiğini varsayan sosyoteknik teoriye göre daha bütüncül bir değerlendirme yapmak için takımın hem teknik özelliklerine ilişkin hem de sosyalleşme özelliklerine ilişkin sonuçlarının değerlendirilmesi gerekmektedir. Teknik yön, çıktılara dönük eylemler ile ilgiliyken sosyalleşme yön, takım üyelerinin birbirleriyle olan ilişkileri ile ilgilidir. Her iki sistemin de yüksek çıktılar ve olumlu sosyalleşme deneyimler için optimize edilmesi gerekir. Dolayısıyla sosyalleşme deneyimleri performanstan ayırmak mümkün değildir (Senior ve Swailes, 2004: 319).

Benzer şekilde Jones ve Goffee (1996), organizasyon temelli tüm yapılanmalarda (iş takımları, aile, kulüp gibi) insan davranışlarının iki farklı yönden analiz edilebileceğini öne sürmektedir: topluluk üyeleri arasındaki dostluk derecesi olarak tanımlanabilecek olan "sosyalleşmeleşme" ve bir grubun ortak bir hedefe yönelme ve ulaşma yeteneğinin bir göstergesi olarak tanımlanan "dayanışma". Eğer bir performans değerlendirmesi yapılacaksa bu iki boyutun birlikte ele alınması gerekmektedir.

\section{Sosyalleşme performansı}

Sosyalleşme performansı, operasyonel olmayan ve duygusal ilişki derecesinin bir göstergesidir (Ortiz ve CruzFreire, 2012: 20). Bir takımın çoğu kez doğal olarak ortaya çıkan ve gelişen sosyalleşme performansı, takım çalışmasını, gönüllü bilgi paylaşımını teşvik etmektedir. Sosyalleşmenin yüksek düzeyde olduğu bir iş yerinde çalışanlar, yüksek moral ve dinamizm sahibi olmakta ve bu durum çalışanlarda performansa karşı bir heves oluşturmaktadır (Goffee ve Jones, 1998: 43-49). Sosyalleşme performansı, bireyin çalışma ortamında kişisel ilişkilerini düzenlemekte ve şekillendirmektedir (Van Maanen ve Schein, 1979: 213). Takım üyeleri arasında dostane, resmi olmayan ilişkiler, çalışma dışı ortamlarda geçirilen vakit ve uyum takım içerisindeki yüksek düzeyde sosyalleşme performanstan kaynaklanmaktadır (Pinto, Cabral-Cardoso, ve Werther Jr., 2011: 380). Çalışanların sosyalleşme performansı sadece kendileri için değil ayn zamanda organizasyon için de değerlidir. Bireyler için sosyalleşme, öz yeterliliklerini artırmaya ve iş doyumlarını iyileştirmeye yardımcı olurken (Feldman, 1981: 310); organizasyonlar için çalışanların entegrasyon sürecinin kısalmasına ve örgütsel bağlılı̆̆ının artmasına yardımcı olabilmektedir (Liao, Huang, ve Xiao, 2016: 94).

\section{Dayanışma performansı}

Dayanışma performansı, duygulara değil, ilişkinin ilgili tüm taraflarca paylaşılan ortak görevler, hedefler veya karşılıklı çıkarlarda kurulduğu entelektüel düşünceye dayanmaktadır (Ortiz ve CruzFreire, 2012: 20). Bir topluluğun kişisel bağlarından bağımsız olarak, ortak hedefleri hızlı ve etkili bir şekilde gerçekleştirme becerisinin bir ölçüsüdür (Jones ve Goffee, 1996). Dayanışma performansı, enerji, yoğunlaşma, odaklanma ve bir şeyleri gerçekleştirme dürtüsü ile karakterize edilmektedir. Ortak çıkarları paylaşan ve bunları takım olarak gerçekleştirmenin avantajlarını algılayan üyeler arasında ortaya çıkmaktadır (Pinto vd., 2011: 380). Dayanışma davranışı, bir bireyin bir organizasyonun yararına yaptığı katkıyı ifade etmektedir ve organizasyonun hedefine ulaşmak için fazladan çaba gösterme isteğinden kaynaklanır (Moskovich, 2016: 358). Yönetim anlayışı, resmi kontrol ve prosedürlerle dayanışma davranışını etkilemektedir. Oyunun kuralları konusunda şeffaflık ve üretken davranış için verilen ödüller dayanışmayı artırırken çalışanlar ödül ve terfilerde adaleti hissettiklerinde, iş tatmini ve dayanışma performansı yükselme eğilime girmektedir (Miller ve Monge, 1986: 730). Yüksek düzeyde dayanışma, bireysel ve organizasyonel anlamda birçok olumlu duygularla sonuçlanmaktadır (Sanders ve Van Emmerik, 2004: 359).

\section{Takım devamlılığı}

Takım devamlılığı; üyelerin birlikte çalışmaya devam etme istekliliği (Sundstrom, Meuse, ve Futrell, 1990: 122) ve takımın gelecekteki performans bölümlerinde başarısı için gerekli olan sürdürülebilirlik ve büyüme kapasitesidir (Bell ve Marentette, 2011: 279). Takım devamlılı̆̆1, ekip üyelerinin zaman içinde bir arada kalırken iç ve dış değişikliklere uyum sağlama ve zaman içinde etkili performans düzeylerini sürdürme becerilerini yansitır (Costa, Passos, ve Barata, 2015: 20).

Yeni teknolojiyle çalışma veya pazardaki dalgalanmalara ve değişikliklere sürekli olarak adapte olma ihtiyacı gibi takımların günümüzde karşılaştığı zorluklar göz önüne alındığında, takımın uyum sağlama ve birlikte çalışmaya devam etme kapasitesini artıran koşulları ve süreçleri keşfetmek önem kazanmaktadır (Dimas, Rocha, Rebelo ve Lourenço, 2017: 561). Takım devamlılı̆̆ını anlamak, ilgili kişilere, takımın gelecekteki performans taleplerine uyum sağlamak için sahip olduğu potansiyeli hakkında bilgi sağlar (Jeczmien, Chomatowska, Janiak-Rejno, ve Żarczyńska-Dobiesz, 2019: 157). 
Yöneticiler, takım devamlılı̆̆ını anladığında, devam eden ekipleri başarılı performansa yönlendirmek için proaktif bir yaklaşım benimseyebilir.

Takım devamlılığı, bir ekibin mevcut davranışlarını iyileştirmesi gerekip gerekmediğine ve gelecekte birlikte iyi çalışıp çalışmayacaklarına dair önemli işaretler verir (Cooperstein, 2017: 3). Devamlılık sağlayan takımlar, başarılı performans stratejilerini nasıl geliştireceklerini, birbirleriyle etkili bir şekilde nasıl çalışacaklarını ve görev motivasyonunu nasıl sürdüreceklerini bilirler (Cooperstein, 2017: 8). Takımın devamlılığı, ekip içerisinde gerçekleşen gayri resmi bağlantılarla desteklenir. Birbirleriyle sık iletişim kuran üyeler potansiyel çatışma kaynaklarının belirlenmesi ve bunların çözümü konusunda daha başarılıdır. Bu tür takımlar genellikle parçalanmaya ve üye kaybına neden olan zararlı ilişkisel veya sosyo-duygusal çatışmaya direnirler (Balkundi ve Harrison, 2006: 52). Takım üyeleri, takımlarında olumlu deneyimler yaşadıkça, takımlarının hedef ve değerleriyle özdeşleşecekler ve takım hedeflerine katkıda bulunmak için takımda kalmak isteyeceklerdir (Mowday, Steers, ve Porter, 1979: 225). Olumlu deneyimler yaşama, takıma uyum sağlama ile yakından ilişkilidir. Takım içi uyumun gerçekleşmesi, takım üyelerinin etkinliğini, performansını ve yeniden birlikte çalışma isteğini olumlu yönde etkilemektedir (Maynard, 2015: 654). Uyum yeteneğine sahip takımlar, etkileşimlerini çevrenin değişen taleplerine uyacak şekilde değiştirme yeteneklerine sahip olduklarından, yeni görev koşulları altında yüksek düzeyde performans gösterebilirler (Gorman, Cooke, ve Amazeen, 2010: 295). Ayrıca zorluklarla başa çıkma, ihtiyaç duyulan kaynakları koruma veya yenileme, hataları telafi etme becerilerinden dolayı uyumlu takımların devamlılığı daha mümkün ve kolaydır (Alliger, Cerasoli, Tannenbaum ve Vessey, 2015: 179).

\section{Yöntem}

\section{Araştırmanın yöntemi}

$\mathrm{Bu}$ araştırmada, takım oluşturma, takım performansı ve takım devamlılığı arasındaki ilişkileri incelemeyi amaçlanmaktadır. Bu kapsamda araştırma, nicel araştırma yöntemlerinden ilişkisel tarama modelinin temel aldığı felsefe ve bakış açısı dikkate alınarak tasarlanmıştır. Kullanılan verilerin özelliklerine göre birincil ve kesitsel (anlık) verilere dayanırken, denek sayısına göre çok denekli (faktöriyel desenli), deneme ve ölçme koşullarına göre ise karışık desenli bir çalışmadır.

\section{Araştırma birimi, evren ve örneklemi}

Araştırma evrenini farklı sektörlerdeki örgütlerde farklı büyüklükteki takımlarda görev yapan takım üyeleri oluşturmaktadır. Evrende yer alan takım ve üye sayıları tam olarak bilinmemektedir. Ayrıca 2020 yılı Mart Ayı'ndan itibaren yaşanan küresel COVID-19 salgını nedeniyle kolayda örnekleme yöntemi tercih edilmiştir. Literatürde bilinmeyen evrenlerden örneklem grubu oluşturmak için bazı formülasyonlar geliştirilmiştir. Bu araştırmada geçerliliği kabul edilen bu formüllerden yararlanılmış ve örneklem sayısını hesaplamak için $=\frac{\mathrm{t}^{2} \text {.p.q }}{\mathrm{d}^{2}}$ formülü kullanılmıştır (Karagöz, 2014). Formülde yer alan: n: örneklem sayısını, p: ana kütledeki incelenen olayın gerçekleşme olasılığı, q: ana kütledeki incelenen olayın gerçekleşmeme olasılığı, t: belirli bir anlamlılık düzeyini, d: tahmin edilecek olan ana kütle oranı ile aynı ana kütleden alınan örneklem arasındaki sapma miktarını ifade etmektedir. Olayın gerçekleşme olasılığı $\mathrm{p}=0.5$, olayın gerçekleşmeme olasılığ $\mathrm{q}=0.5, \mathrm{a}=0.05$ de $\infty$ serbestlik derecesindeki $\mathrm{t}$ değeri $\mathrm{t}=1.96$ ve örnekleme hatası $\mathrm{d}=0,06$ olarak alınmıştır. İlgili değerler formüle uygulandığında, araştırma için ulaşılması gereken örneklem sayısı $(n)=267$ olarak belirlenmiştir. Bununla birlikte araştırma sonuçlarının genellenebilirliğini artırmak amacıyla veri toplama aracında yer alan madde sayısının en az beş katına ulaşmak kabul edilebilir bir kriter olarak değerlendirilmektedir (Bryman ve Cramer, 2001; Büyüköztürk, 2002). Bu doğrultuda araştırmada toplamda 30 maddelik bir ölçek formunun kullanıldığı dikkate alındığında, 375 katılımcıya ulaşılmış olması istatistiki olarak geçerli sonuçların elde edilebileceğini göstermektedir.

\section{Araştırmanın veri toplama tekniği ve süreci}

Araştırmada veri toplama aracı olarak çevrimiçi anket yöntemi tercih edilmiştir. Literatüre dayalı olarak hazırlanan anket formu 4 bölümden oluşmaktadır. İlk bölümde çalışanların takım devamlılı̆̆ ile ilgili görüşlerini ifade eden 10 madde, ikinci kısımda çalışanların takım oluşturma süreçleriyle ilgili görüşlerini ifade eden 11 madde, üçüncü bölümde çalışanların takım performansı ile ilgili görüşlerini ifade eden 17 madde ve son bölümde demografik özellikleri ifade eden 8 madde bulunmaktadır. Demografik özelliklere ait sorular çoktan seçmeli olarak hazırlanırken, takım oluşturma, takım performansı ve takım devamlılığı ile ilgili algıları ölçmek için, orijinal ölçeklerinde olduğu gibi, 5'li likert tipi değerlendirme ölçütleri (1-Kesinlikle Katılmıyorum, 2-Katılmıyorum, 3-Kararsızım, 4Katılıyorum, 5-Kesinlikle Katılıyorum) kullanılmıştır. Ankette yer alan ifadelerin dilsel geçerliliğini sağlanmak için ölçekler yeminli tercümanlar aracıllğı ile İngilizce' den Türkçe' ye çevrilmiştir. Kapsam 
geçerliliği içinse anket formu, alanında uzman akademisyenler tarafından kapsayıcılık, anlaşılabilirlik ve araştırma amacına hizmet edebilme açısından değerlendirilmiştir. Teorik ifadelerle ilgili uzmanların eleştirileri ve önerileri dikkate alınarak ankette gerekli düzenlemeler yapılmıştır. Oluşturulan anket formu Düzce Üniversitesi Etik Kurul onayına sunulmuş, bilimsel araştırma ve yayın etiğine uygunluğu kontrol edildikten sonra uygulama aşamasına geçilmiştir. Anket formu surveey.com sitesi üzerinden çevrimiçi anket olarak hazırlanmıştır. Genel uygulanmaya başlanmadan önce, sistematik veya rastgele hataların önüne geçebilmek amacıyla katılımcılara yöneltilen soruların doldurma süresi, uygunluğu, zorluk derecesi ve anlaşılabilirliğini görmek amaciyla 50 kişi üzerinden bir pilot çalışma gerçekleştirilmiştir. Pilot çalışma sonrasında, katılımcıların anket formuna bir link aracılığıyla ulaşmaları sağlanmış, veriler, 1 Nisan 2021-20 Nisan 2021 tarihleri arasında toplanmıştır.

\section{Ölçekler}

Yapılan literatür taraması sonucunda araştırma modelinde yer alan değişkenlerle ilgili açıklayıcı nitelikte bazı önemli çalışma ve ölçeklere rastlanmıştır. Araştırmanın amacı ve yöntemi doğrultusunda bu ölçeklerden faydalanılmıştır. Takım oluşturma ölçeği için Aga vd. (2016) tarafından geliştirilen ölçekten yararlanılmıştır $(\alpha=0,931)$. Klein vd.'nin (2009) yaptığı meta analiz incelemesine bağlı olarak geliştirilen bu ölçek; hedef belirleme, kişilerarası ilişkiler, rol belirleme ve problem çözme olarak çok boyutlu yapıları içermektedir (Klein vd., 2009; Salas vd., 1999). Literatürde bu boyutların ayrı ayrı ele alınabildiği gibi bir bütün olarak da ele alındığı görülmektedir (Wildmeyer ve Ducharme, 1997; Locke ve Latham, 2002; Eys ve Carron, 2002; Senécal vd., 2008; Lin vd., 2015). Bu araştırmada takım oluşturma, tartışılan tüm özellikleri kapsayacak şekilde, tek boyut (11 madde) olarak incelenmiştir. Takım performansı ile ilgili literatür incelendiğinde, konunun daha çok etkililik ve verimlilik çerçevesinde ele alındığı görülmektedir. Geliştirilen ölçekler tek boyutlu ve daha çok takım etkinliğini ölçmeye yöneliktir. Bu araştırmada literatürde hâlihazırda mevcut ölçeklerin bakış açılarından yararlanmakla birlikte konuyu daha bütüncül değerlendirmek adına takım performansı ölçeği, Goffee ve Jones, (1998)'un çalışmalarından esinlenilerek oluşturulmuştur. Sosyalleşme performans ve dayanışma performansı olmak üzere 2 boyut şeklinde tasarlanan ölçekte, takım üyelerinin sosyalleşme performans düzeyini ölçmek için 8 madde, dayanışma performans düzeyini belirlemek için 9 madde yazılmıştır. Araştırmanın bir diğer değişkeni olan takım devamlılığı için Aubé ve Rousseau (2005) ve Cooperstein'ın (2017) literatürdeki takım devamlılığı ölçeklerinden yararlanılmıştır $(a=0,840)$. Ölçek tek boyutlu ve 7 maddeden oluşturmaktadır.

\section{Araştırmanın modeli ve hipotezleri}

Araştırma modeli literatür taraması ve araştırmacıların takımların yönetimine ilişkin bireysel gözlemlerine dayalı olarak oluşturulmuştur. Takım çalışmasının genel niteliklerini ortaya koyan bu modelde 3 temel değişken bulunmaktadır: takım oluşturma, takım performansı ve takım devamlılığı. $\mathrm{Bu}$ değişkenlerden takım oluşturma ve takım devamlılığı tek boyutluyken takım performansı, sosyalleşme performans ve dayanışma performansı olmak üzere iki boyutludur. Modelin görünümü ve değişkenler arasındaki ilişkileri gösteren ayrıntılar Şekil 1'de gösterilmektedir.

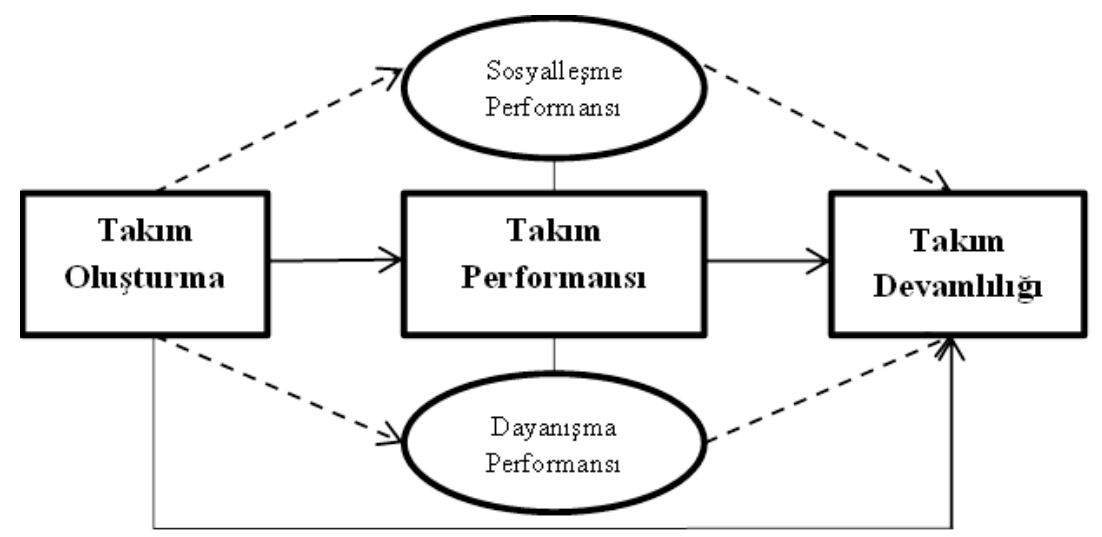

Şekil 1: Araştırma Modeli

Araştırma modelinde, doğrudan ve dolaylı (aracılık) ilişkiler olmak üzere iki tür ilişki görülmektedir. Doğrudan ilişkiler değişkenler arasındaki ikili ilişkileri açıklarken dolaylı (aracılık) ilişkiler değişkenler arasındaki üçlü ilişkileri açıklamaktadır.

Literatür incelendiğinde takım oluşturma sürecinin başarılı bir şekilde gerçekleşmesinin takım performansı ve takım devamlılığına etki ettiğine dair bulgulara rastlanmaktadır (Aga vd., 2016: 812; Bartlett vd., 1999: 307-308). Örneğin, Lyubovnikova, Legood, Turner, ve Mamakouka, (2015: 65) tarafından yapılan çalışmada, takım üyelerinin uygun bir şekilde seçiminin takım performansının 
artmasına yol açtığı sonucuna ulaşılmıştır. Benzer şekilde Ammeter ve Dukerich (2002: 10) araştırmalarında uygun takım oluşturmanın, takım devamlılığına katkı sağladığı ve daha yüksek bir takım performansı ile sonuçlandığını bulmuşlardır. Spesifik anlamda düşünüldüğünde ise takım oluştururken rol belirlenmesine dikkat edilmesinin çatışmayı ve belirsizliği azaltacağı (Tannenbaum vd., 1992: 120), rollerin ve sorumlulukların daha net bir şekilde tanımlanmasıyla ekip üyelerinin kendilerinin ve ekip arkadaşlarının sorumluluklarını daha iyi anlayacağı tartışılmaktadır (Salas vd., 1999: 316). Böylelikle takım üyeleri rolleriyle ilgili aralarında çıkabilecek sorunların üstesinden gelecek ve takım etkinliği artacaktır (Lacerenza vd., 2018: 524).Ayrıca yüksek düzeyde rol netliğine sahip organizasyonlar, daha yüksek iş memnuniyeti ve daha düşük işten ayrılma oranlarına sahiptirler (Hassan, 2013: 716). Rollerin net olması, işletmeye olan bağlılığı artırarak, işten ayrılma niyetini azaltmaktadır (Panaccio ve Vandenberghe, 2011: 1455). Dolayısıyla rollerin belirliliği, takım devamlılı̆̆ını pozitif yönde etkileyecektir. Aynı şekilde hedef belirleme, eylem odaklı çabanın artmasını sağlayarak başarma motivasyonuna kaynak sağlayacak (Locke vd., 1981: 131) doğru yönlendirme ile takım üyelerini iş yapmanın verimli yollarını araştırmaya teşvik edecektir (Yukl, Gordon ve Taber, 2002: 19). Hedeflerin net ve kesin olması, "elinden geleni yap" gibi belirsiz hedeflere kıyasla daha yüksek performansla sonuçlanacaktır (Locke vd., 1981: 125). Bazı araştırmalarda özellikle zor ve açık bir hedef belirlemenin performansı artıracağı savunulmaktadır (Buller ve Bell, 1986: 323). Yine kişilerarası ilişkilerin güçlendirilmesi, karşılıklı destek ve güveni geliştirecek. Dolayısıyla açık bir iletişimle çatışmalarla yüzleşilecek ve çatışmaların çözülmesiyle daha etkili kararların alındığı bir ortam oluşturulacaktır (Liebowtiz ve De Meuse, 1982: 7). İletişimin artması ve kişilerarası ilişkilerin düzenlenmesiyle birlikte takımın birlikte çalışma eğilimi, etkinliğini ve üretkenliğini artmaya başlayacaktır (Argyris, 1962: 712). Dinamik bir bilgi alışverişi sağlayan kişilerarası güçlü iletişim, kişiyi başkalarıyla bağlantılı kılarak gruplar halinde var olmayı ve çalışmayı daha mümkün hale getirecektir (Anant, 2015: 431). Bir grup içindeki kişilerarası ilişkilerin olumlu olması bireysel uyumu kolaylaştıracak (Macgrath, 1962: 365) dolayısıyla takım içerisinde bireysel uyumun kolayca sağlandığı ve kişilerarası ilişkilerin olumlu olduğu bir takımda devamlılığının sağlanması daha kolay olacaktır. Son olarak problem çözme etkinliği, takım üyelerinin önemli sorunları belirlemesine, kritik bilgi üretmesine, problem çözme ve eylem planlarının uygulanmasına katılımını sağladığı için (Buller ve Bell, 1986: 149-150) takımların birlikte büyük problemleri çözerek daha etkili ve devamlı hale gelmelerine yardımcı olmaktadır (Tannenbaum vd., 1992: 120). Takım içerisinde, bireylerin problemleri çözmeye yönelik ortak bir çaba göstererek sinerji oluşturması ve deneyimlerin paylaşılması daha yüksek performansa da katkıda bulunmaktadır (Jordan ve Troth, 2004: 208). Ayrıca takım devamlılı̆̆ı, takım üyelerinin zaman içinde birlikte çalışmaya devam etme yeteneğine sahip olduğu anlamına geldiği için (Aube ve Rousseau, 2011: 567) performansları vesilesiyle etkinliği yüksek olan takımlar, daha yüksek oranda takım devamlılı̆g göstereceklerdir. Diğer taraftan performansı yüksek takımlar genelde sosyal ilişkilerin ve dayanışma motivasyonunun üst düzey olduğu takımlardır. Sosyalleşme performans genelde bilgi paylaşımını ve yeni fikirlere açık hale gelmeyi sağlamasının yanı sıra çalışanların takım arkadaşlarını yarı yolda bırakmak istemesini de engellemektedir (Goffee ve Jones, 1998: 47-49). Dolayısıyla takım içerisinde dostluk ilişkisi kuran çalışanların birlikte çalışma istekliliği artacak ve bu durum takım devamlılı̆̆ını pozitif yönde etkileyecektir. Aynı şekilde dayanışma performansı, takım üyelerinin müşterek ilgi alanlarına, ortak görevlerine ve açıkça kavranmış paylaşılan ortak hedeflerine dayandığı için takım devamlılı̆̆ına pozitif etki edecektir. Gelecekteki davranışın en iyi yordayıcısının geçmiş davranış olması gibi, gelecekteki performansın önemli bir yordayıııs da mevcut performans olmasından (Bell ve Marentette, 2011: 284) dolayı mevcut takım performansının takım devamlılığını tahmin etmesi beklenmektedir. Bu bilgiler doğrultusunda araştırma hipotezleri aşağıdaki gibi oluşturulmuştur:

“ $\mathrm{H}_{1}$ : Takım oluşturma, takım devamlılığı üzerinde pozitif yönlü bir etkiye sahiptir".

" $\mathrm{H}_{2}$ : Takım performansı, takım devamlılı̆̆ üzerinde pozitif yönlü bir etkiye sahiptir".

" $\mathrm{H}_{3}$ : Takım oluşturma, takım performansı üzerinde pozitif yönlü bir etkiye sahiptir".

Son olarak takım oluşturma süreçlerinin etkili şekilde yönetilmesiyle olası problemler engellenecektir. Takım içerisinde bir problemin olmaması, görevlerin ve hedeflerin belli olması takım içindeki birlikte çalışma istekliliğini artıracaktır. Bu isteklilik takım devamlılığına olumlu yansıyacaktır. Fakat her ne kadar hedeflerin, rollerin belirliliği ve problemlerin çözümü gibi iyi bir süreçten geçerek oluşturulan takımlar devamlılık konusunda sorun yaşamayacak gibi görünse de eğer bir takım yeterli performans gösteremezse bir müddet sonra takımın devamlılığı tartışma konusu olabilir. Çünkü takımlar yeterli performans gösterdikleri takdirde devam ederler. Uyum önemlidir fakat performans daha belirleyicidir. Uyumlu olduğu halde dağılan birçok takıma rastlamak pek ala mümkündür. Fakat performansı iyi olduğu halde dağılan takım sayısı nispeten daha azdır. Buradan hareketle iyi 
oluşturulan takımların ancak iyi performans gösterdikleri takdirde takım devamlılığını sürdüreceği savunulabilir. Bu çerçevede takım oluşturma ile takım devamlılı̆̆ı arasındaki ilişkide takım performansının anlamlı bir aracılık etkisine sahip olabileceği düşünülmektedir. Bu çıkarımlar doğrultusunda " $\mathrm{H}_{4}$ : Takım oluşturma ile takım devamlılığı arasındaki ilişkide takım performansı aracllık etkisine sahiptir" hipotezi geliştirilmiştir.

Ayrıca takım performansı özelinde düşünüldüğünde sosyalleşme performansının her koşulda takım devamlılığına pozitif yönlü yansıyacağı konusunda da bazı endişeler bulunmaktadır. Goffee ve Jones (1998) konuya ilişkin olumsuz sosyalleşme durumunu gündeme getirmektedir. Yani bazı organizasyonlarda sosyalleşme düzeyi çok yüksek olmasına rağmen sonuç ve performansa dönük gayret istenilen düzeyde gerçekleşmemekte ve bu durum zamanla gruplarda dağılma yönlü eğilimlere neden olabilmektedir. Bu anlamda dayanışma performansı; hedefleri tutturmak için çok ciddi şekilde çalışma, kazanmayı gönülden arzulama, rakipleri yenmeye çok azimli olma, işle ilgili talimatlara tam uyum, iş hedefini çok iyi bilme, projeleri çoğunlukla başarılı bir şekilde tamamlama, sorunların kritik noktalarını çok iyi belirleye bilme, kimin görevinin nerede başlayıp nerede bittiğinin gayet belirgin olması gibi özelliklerinden dolayı sosyalleşme performansa nispeten daha sonuç alıcı ve devamlılığa katkı sağlayıcı nitelikte görünmektedir. Bu bilgiler ışı̆̆ında " $\mathrm{H}_{5 \mathrm{a}, \mathrm{b}}$ : Takım oluşturma ile takım devamlılığı arasındaki ilişkide (a) Dayanışma Performansı (b) Sosyalleşme Performansına nispeten daha önemli bir aracilık etkisine sahiptir" hipotezi geliştirilmiştir.

\section{Bulgular}

Katılımcılardan elde edilen veriler analizinde keşifsel analizler için SPSS 21.0 ve doğrulayıcı analizler için LİSREL 8.72 programından yararlanılmıştır. Analizde öncelikle katılımcıların demografik özelliklerini incelemek amacıyla frekans analizi yapılmıştır. Sonrasında modelde yer alan değişkenlerin yapısal geçerliliğini tespit etmek amacıyla keşfedici ve doğrulayıcı faktör analizleri uygulanmıştır. Daha sonra değişkenlere ilişkin betimleyici istatistikler, korelasyon analizi ve model testi için regresyon analizleri gerçekleştirilmiştir. Son aşamada ise en iyi uyum iyiliğine sahip modeli belirlemek için Path analizi yapılmıştır.

Araştırmanın örneklem grubu özelliklerini ve kapsam/geçerlilik sınırlarını belirleyebilmek adına öncelikle katılımcıların özellikleri incelenmiştir. Elde edilen bulgulara göre katılımcıların büyük çoğunluğu erkeklerden oluşmakta $(\% 61,3)$ ve $25-34$ yaş aralığında $(\% 53,1)$ yer almaktadır. Öğrenim durumu itibariyle katılımcılar daha çok lisans $(\% 57,9)$ ve yüksek lisans $(\% 21,6)$ eğitim düzeyine sahiptirler. Katılımcılar çoğunlukla 1-5 yıl arası bir deneyime sahipler, statü olarak yönetici pozisyonlarından ziyade çalışan statüsünde $(\% 55,5)$ yer almakta ve sektörel anlamda oldukça yerleşik kurumlarda (16 ve daha fazla sürede faaliyet gösteren) çalışmaktadırlar $(\% 48,5)$.

Değişkenlere ilişkin yapısal geçerliliği tespit etmek ve model testi için öncelikle takım oluşturma, takım devamlılığı ve takım performansı değişkenlerine yönelik keşifsel faktör analizi gerçekleştirilmiştir. Analize iliş̧in detaylar Tablo 1'de sunulmaktadır.

Tablo 1: Keşifsel Faktör Analizleri

\begin{tabular}{|c|c|c|c|c|c|c|c|}
\hline Faktörler & Madde & KMO & $\begin{array}{l}\text { Bartlett's } \\
\text { Test }\end{array}$ & $\begin{array}{l}\text { Çıkarım } \\
\text { Metodu }\end{array}$ & $\begin{array}{c}\text { Rotasyon } \\
\text { Metodu }\end{array}$ & $\begin{array}{l}\text { Açılanan } \\
\text { Varyans }\end{array}$ & Özdeğer \\
\hline Takım Oluşturma & 8 & 880 & \multirow{4}{*}{,000 } & \multirow{4}{*}{$\begin{array}{l}\text { Principal } \\
\text { Component } \\
\text { Analysis }\end{array}$} & \multirow{4}{*}{ Varimax } & 51,649 & 4,132 \\
\hline $\begin{array}{l}\text { Takım Performansı (Dayanışma } \\
\text { Performansı) }\end{array}$ & 8 & \multirow{2}{*}{,937 } & & & & 36,289 & 7,781 \\
\hline $\begin{array}{l}\text { Takım Performansı } \\
\text { (Sosyalleşme Performansı) }\end{array}$ & 7 & & & & & 29,711 & 2,119 \\
\hline Takım Devamlılığı & 7 & 916 & & & & 67,373 & 4,716 \\
\hline
\end{tabular}

Tablo 1 incelendiğinde veri setinin faktör analizine uygunluğu tespit etmek için dikkate alınan KMO değerlerinin tüm değişkenler (takım oluşturma, sosyalleşme performans, dayanışma performansı, takım devamlılığı) için çok iyi düzeyde skor ürettiği (eşik değer 0,60 üzeri) ve Bartlett testi sonuçlarının istatistiksel olarak anlamlı olduğu görülmektedir. Diğer taraftan faktör analizi için çıarım metodu olarak temel bileşenler analizi ve rotasyon yöntemi olarak varimax döndürme tekniği kullanılmış, 0,45'nin altında kalarak düşük eşdeğerlik gösteren ifadeler ölçekten çıkarılmıştır. Bu doğrultuda takım oluşturma için analize alınan 11 maddeden 3 tanesi; takım performansı için 17 maddeden 2 tanesi; takım devamlılı̆̆ için 10 maddeden 3 tanesi, birden fazla faktörde yüksek faktör yükü verdiğinden (binişik madde) yapılardan çıkarılmıştır. Son tahlilde elde edilen faktörlerin ölçeklere ilişkin açıkladıkları varyans miktarının sosyalleşme bilimler için oldukça iyi düzeyde oldukları görülmektedir. Ayrıca tüm faktörlerde yer alan maddelerin faktör yükü değer aralıkları 
(takım oluşturma için 0,782 ile 0,634 arasında, dayanışma performansı için 0,782 ile 0,634 arasında, sosyalleşme performans için 0,782 ile 0,634 ve takım devamlllı̆̆ için 0,782 ile 0,634 arasında) birbirine oldukça yakındır. Bu durum faktörlerin içsel tutarlılığının yüksek olduğunu göstermektedir.

Açımlayıcı faktör analizi sonrasında değişkenler için tanımlayıcı istatistikler, güvenirlik katsayıları ve korelasyon analizi sonuçları incelenmiştir. İlgili ayrıntılar Tablo 2'de sunulmaktadır.

Tablo 2: Betimleyici İstatistikler ve Korelasyon Analizi

\begin{tabular}{|c|c|c|c|c|c|c|c|c|c|}
\hline Değişkenler & Ort. & Std. Sap. & Skew. & Kurto. & a & TAKO & DAP & SOP & TKD \\
\hline Takım Oluşturma (TAKO) & 4,0220 & 67036 & $-1,118$ & 2,337 & 865 & 1 & & & \\
\hline Dayanışma Performans (DAP) & 4,0597 & ,75143 & $-1,189$ & 1,868 & ,928 &, $770^{* *}$ & 1 & & \\
\hline SosyalleşmePerformansı (SOP) & 3,6396 & 84184 &,- 407 &,- 107 & ,904 &, $559^{* * *}$ &, $573^{\text {** }}$ & 1 & \\
\hline Takım Devamlılığı (TKD) & 4,0171 & 76296 & $-1,201$ & 1,937 & ,919 &, $750^{\text {*t }}$ & ,759 *t* &, $529^{\text {*k }}$ & 1 \\
\hline
\end{tabular}

Tablo 2 incelendiğinde katılımcıların takım oluşturma sürecini $(4,02)$ başarılı buldukları görülmektedir. Takım performansı konusunda dayanışma performansı $(4,05)$ iyi düzeydeyken sosyalleşme performans nispeten düşük düzeydedir $(3,63)$. Katılımcılar mevcut durumda üyesi oldukları takımın devam etmesi gerektiği konusunda olumlu yönde fikir birliğine sahiptirler $(4,01)$. Diğer taraftan değişkenlere ilişkin çarpıklık ve basıklık değerleri kabul edilebilir düzeyde (Basıklık ve çarpıklık katsayılarının -2 ile +2 arasında (Pallant, 2007), -3 ile +3 arasında olması (Kalaycı, 2009) kabul edilebilir düzeyde normal dağılım) olduğu için verilerin normal dağılım gösterdiği söylenebilir. Aynı zamanda tüm değişkenlere ait güvenilirlik katsayıları, literatürde geçerli sayılan eşik değerin (a: 0.60 ) üzerindedir. Bu bulgular değişkenleri oluşturan ifadelerin (ölçek maddelerinin) güvenilir olduğunu göstermektedir. Değişkenler arasındaki ilişkiler incelendiğinde ise takım oluşturma ile dayanışma performansı ve takım devamlılığı arasında yüksek düzeyde pozitif yönlü bir ilişki tespit edilirken takım oluşturma ile sosyalleşme performans arasında orta düzeyde pozitif yönlü bir ilişki bulunmuştur. Benzer şekilde dayanışma performansı ile takım devamlılığı arasında yüksek düzeyde sosyalleşme performansı ile takım devamlılığı arasında orta düzeyde pozitif yönlü bir ilişki tespit edilmiştir.

Değişkenler arasındaki ilişkiye yönelik eğilimlerden etkiye dönük işaretler anlaşıldıktan sonra araştırma modelinin testi için regresyon analizleri gerçekleştirilmiştir. Regresyon analizleri ile ilgili ayrintılar Tablo 3'te sunulmaktadır.

Araştırma modelini test etmek için gerçekleştirilen regresyon analizlerinde hiçbir modelde çoklu bağlantılılık (multi-colinearity) rastlanmamıştır. Değişkenlerin açıklayamadıkları varyans oranı olan tolerans değeri en düşük 0,44 olarak $\left(0,20^{\prime}\right.$ den daha düşükse sorunlu) ve VIF değeri 1 olarak (10'dan yüksekse sorunlu) hesaplanmıştır. Değişkenler ile hata terimleri ilişkisini incelemek için dikkate alınan Durbin-Watson katsayısı (en yüksek 1,954) bağımsız değişkenler ile hata terimleri arasında sorunlu bir ilişkinin olmadığını göstermektedir (Büyüköztürk, 2006: 100). Ayrıca araştırma modelinin temel kurgusunu oluşturan aracilık etkisini ölçmek için M1, M2 ve M3 modellerinin ön koşul şeklinde istatistiki olarak anlamlı olması gerekmektedir. Bu kapsamda tablo 3 'teki analiz sonuçlarına göre genel anlamda tüm değişkenlerin anlamlı bir yordayıcı olma özelliğine sahip olduğu söylenebilir. Dolayısıyla bir aracılık ölçümünün gerçekleştirilmesi mümkündür. Spesifik anlamda modeller incelendiğinde, takım oluşumunun takım devamlılığı üzerinde pozitif yönlü önemli düzeyde anlamlı bir etkisinin olduğu görülmektedir (M1). Bu etki, aracılık analizinin birinci varsayımının (bağımsız değişkenin aracı değişken üzerinde anlamlı etkisinin olması) gerçekleştiğini göstermektedir. $\mathrm{Bu}$ doğrultuda " $\mathrm{H}_{1}$ : Takım oluşturma, takım devamlılığı üzerinde pozitif yönlü bir etkiye sahiptir" hipotezi kabul edilmiştir. Aynı şekilde takım performansı da takım devamlılığı üzerinde anlamlı bir etkiye sahiptir (M2). Bu durum, aracılık analizinin ikinci varsayımını (muhtemel aracılık rolüne sahip değişkenin bağımlı değişken üzerinde anlamlı etkisinin olması) doğrular niteliktedir. Bu kapsamda " $\mathrm{H}_{2}$ : Takım performansı, takım devamlılı̆̆ üzerinde pozitif yönlü bir etkiye sahiptir" hipotezi de kabul edilmiştir. Son olarak takım oluşumunun takım performansı üzerinde anlamlı bir etkiye sahip olduğu tespit edilerek (M3) aracılık analizinin üçüncü varsayımı (bağımsız değişkenin muhtemel aracılık rolüne sahip değişken üzerinde anlamlı bir etkiye sahip olması) sağlanmıştır. Bu bulgular ışığında " $\mathrm{H}_{3}$ : Takım oluşturma, takım performansı üzerinde pozitif yönlü bir etkiye sahiptir" hipotezi kabul edilmiştir. Aracılık analizine ilişkin temel varsayımlar sağlandıktan sonra gerçekleştirilen aracılık testi (M4) sonuçlarına göre takım performansı ve takım oluşumu değişkenlerinin modele dâhil edilmesiyle birlikte takım oluşumu değişkenin takım devamlılığı üzerindeki etkisinde $\beta$ katsayıları ve 
t değerlerindeki değişim itibariyle dikkat çekici bir düşüş yaşanmıştır. Bu düşüşün istatistiki olarak anlamlı olup olmadığı tespit etmek için Sobel Testi hesaplaması gerçekleştirilmiştir.

Tablo 3: Takım Oluşturma, Takım Performansı, Takım Devamlılığı Regresyon ve Aracılık Analizleri

\begin{tabular}{|c|c|c|c|c|c|c|}
\hline \multirow{2}{*}{\multicolumn{2}{|c|}{ Model Değişkenleri }} & \multicolumn{2}{|c|}{$\begin{array}{l}\text { Standardize } \\
\text { Edilmemiş Katsayılar }\end{array}$} & \multirow{2}{*}{\begin{tabular}{|c|}
$\begin{array}{c}\text { Standardize } \\
\text { Edilmiş Katsayılar }\end{array}$ \\
Beta
\end{tabular}} & \multirow[t]{2}{*}{$t$} & \multirow[t]{2}{*}{$\mathbf{p}$} \\
\hline & & B & Std. Hata & & & \\
\hline \multirow{2}{*}{ M1 } & (Constant) &, 582 & ,159 & & 3,664 & 000 \\
\hline & Takım Oluşturma &, 854 & ,039 & 750 & 21,931 & 000 \\
\hline \multicolumn{7}{|c|}{$\begin{array}{l}\text { Bağımlı Değisken: Takım Devamlılı̆̆ } \\
\text { r: ,750 r2: } \text { r }^{2}: 563 \mathrm{~F}_{(1-373)}: 480,981 \quad \text { p: ,000VIF: } 1.000 \text { Durbin-Watson: } 1.807\end{array}$} \\
\hline \multirow{2}{*}{ M2 } & (Constant) & 1,031 & ,152 & & 6,777 & 000 \\
\hline & Takım Performans1 & ,776 & ,039 & ,719 & 19,960 & 000 \\
\hline \multicolumn{7}{|c|}{$\begin{array}{l}\text { Bağımlı Değişken: Takım Devamlılı̆̆ı } \\
\text { r: ,719 r²: } 516 \quad \mathrm{~F}_{(1-373)}: 398,410 \text { p: ,000VIF: }\end{array}$} \\
\hline \multirow{2}{*}{ M3 } & (Constant) & ,701 & ,149 & & 4,701 & 000 \\
\hline & Takım Oluşturma & ,783 & ,037 & ,742 & 21,406 & 000 \\
\hline \multicolumn{7}{|c|}{$\begin{array}{l}\text { Bağımlı Değissken: Takım Performansı } \\
\text { r: ,742 } \mathrm{r}^{2}:, 551 \mathrm{~F}_{(1-373)}: 458,235 \quad \text { p: }, 000 \mathrm{VIF}:\end{array}$} \\
\hline \multirow{3}{*}{ M4 } & (Constant) & ,310 & ,152 & & 8,323 & 000 \\
\hline & Takım Oluşturma &, 550 & 054 & 483 & 10,148 & 000 \\
\hline & Takım Performansı & ,388 & 051 & 360 & 7,554 & 000 \\
\hline \multicolumn{7}{|c|}{$\begin{array}{l}\text { Bağımlı Değişken: Takım Devamlılı̆̆1 } \\
\mathrm{r:}, 788 \quad \mathrm{r}^{2}:, 621 \quad \mathrm{~F}_{(2-372)}: 305,162 \text { p: ,000VIF: }\end{array}$} \\
\hline \multirow{3}{*}{ M5 } & (Constant) &, 464 & ,159 & & 2,927 & 004 \\
\hline & Takım Oluşturma & 753 & 046 & 661 & 16,330 & 000 \\
\hline & Sosyalleşme Performans1 & ,144 & , 037 & 159 & 3,929 & 000 \\
\hline \multicolumn{7}{|c|}{$\begin{array}{l}\text { Bağımlı Değişken: Takım Devamlılı̆̆ı } \\
\mathrm{r:} \mathrm{,762} \mathrm{r}^{2}:, 581 \quad \mathrm{~F}_{(2-372)}: 257,521 \quad \mathrm{p}:, 000 \mathrm{VIF}:\end{array}$} \\
\hline \multirow{3}{*}{ M6 } & (Constant) & ,316 & ,146 & & 2,158 &, 032 \\
\hline & Takım Oluşturma & 464 & 055 & 408 & 8,403 &, 000 \\
\hline & Dayanışma Performansı & ,452 & , 049 & , 445 & 9,181 &, 000 \\
\hline \multicolumn{7}{|c|}{$\begin{array}{l}\text { Bağımlı Değisken: Takım Devamlılı̆gı } \\
\text { r: }, 802 \quad \text { rr: }^{2}: 644 \quad \mathrm{~F}_{(2-372)}: 336,338 \quad \text { p: ,000VIF: } 2.457 \quad \text { Durbin-Watson: } 1.890\end{array}$} \\
\hline
\end{tabular}

Bağımsız ve aracı değişken ile aracı ve bağımlı değişken arasındaki etkiye ilişkin $\beta$ katsayıları ve standart hata değerleri hesaplama aracına girildikten sonra Sobel Test değeri $p<0,05$ olarak hesaplanmıştır (Preacher ve Leonardelli, 2021). Elde edilen bu sonuç takım performansının, takım oluşumu ile takım devamlılığı arasındaki ilişkide aracılık rolüne sahip olduğunu göstermektedir. Bununla birlikte her ne kadar takım oluşumunun takım devamlılığı üzerindeki doğrudan etkisi azalsa da istatistiki olarak anlamlı etki devam etmiştir. Dolayısıyla bu aracılık ilişkisi tam aracılık olarak değil de ancak kısmi aracılık olarak kabul edilebilir. Bu bulgular ışığında " $\mathrm{H}_{4}$ : Takım oluşturma ile takım devamlılığı arasındaki ilişkide takım performansı aracılık etkisine sahiptir" hipotezi kısmi aracılık şeklinde kabul edilmiştir. Aynı şekilde araştırma modelinde takım performansının alt boyutları olarak gösterilen dayanışma performansı ve sosyalleşme performansının takım devamlılığı üzerindeki aracılık rolü de incelenmiştir. Analiz sonuçlarına göre dayanışma performansı ve sosyalleşme performansın ayrı ayrı modellere dâhil edilmesiyle birlikte takım oluşumu değişkenin takım devamlılığı üzerindeki etkisinde $\beta$ katsayıları ve $t$ değerlerindeki değişim itibariyle kayda değer bir düşüş yaşanmış ve bu düşüşün istatistiki anlamlılığına ilişkin Sobel Test değeri $p<0,05$ çıkmıştır. Elde edilen sonuçlarda takım oluşumu ve takım devamlılı̆̆ arasındaki ilişki ortadan kalkmadığı için hem sosyalleşme performansı hem de dayanışma performansının kısmi aracılık etkisine sahip oldukları söylenebilir. Bunula birlikte dayanışma performansının sosyalleşme performansına nispeten daha güçlü bir aracılık etkisine sahip olduğu görülmektedir. Bu sonuçlara göre " $\mathrm{H}_{5 a, b}$ : Takım oluşturma ile takım devamlılı̆̆ arasındaki ilişkide (a) Dayanışma Performansı (b) Sosyalleşme Performansına nispeten daha önemli bir aracılık etkisine sahiptir" hipotezi kabul edilmiştir.

Araştırma modelindeki değişkenlere ilişkin keşifsel analizlerden sonra araştırma sonuçlarını daha güçlü analizlerle sınamak ve yapısal geçerliliği test etmek için doğrulayıcı ölçüm modelleri 
(doğrulayıcı faktör analizi ve path analizi) üretilmiştir. Modellere ilişkin uyum iyiliği puanları Tablo 4'te sunulmuştur. Literatürde çok sayıda uyum iyiliği indeksi vardır ve model-veri uyumunu en iyi tanımlayan tek bir ölçüt yoktur. Yine bir modelde bu indekslerin tamamının karşılanması oldukça zor bir durumdur. Fakat en azından bazı temel ölçütlerin karşılanması model geçerliliği için zorunludur. Aynı zamanda birkaç uyum iyiliği birlikte kullanılması daha güvenilir sonuçlar üretmektedir. Literatüre göre uyumun iyiliği endeksleri, verilerin önerilen modelle ne ölçüde eşleştiği değerlendirmek için kullanılır ve genel olarak iki gruba ayrılır: Mutlak uyum indeksleri (Absolute fit indices), Artıml uyum indeksleri (Incremental fit indices). Mutlak uyum indeksleri, a priori modelin örnek verilere ne kadar iyi uyduğunu belirler ve hangi modelin en üst düzey uyuma sahip olduğunu gösterir (Hooperve diğerleri, 2008). Bu çalışmada, mutlak uyum ölçütleri olarak beş test kullanılmıştır: Ki-kare test istatistiği (X2/df), RMSEA, GFI, AGFI ve SRMR. Karşılaştırmalı (Miles ve Shevlin, 2007) veya göreceli uyum indeksleri (McDonald ve Ho, 2002) olarak da bilinen artımlı uyum indeksleri ise ki-kare değerini bir temel modelle karşılaştıran bir indeksler grubudur. Bu endeksler, modelin aynı verilere sahip diğer olası modellerle karşılaştırıldığındaki iyilik durumunu ölçer (Maruyama, 1998). $\mathrm{Bu}$ çalışmada, Normlaştırılmamış Uyum İndeksi (NNFI) ve Karşılaştırmalı Uyum İndeksi (CFI) kullanılmıştır.

Tablo 4: Doğrulayıcı Faktör Analizi

\begin{tabular}{|l|l|l|l|l|l|l|l|l|}
\hline Faktörler & $x^{\mathbf{2}}$ & $\mathbf{d f}$ & NNFI & CFI & GFI & AGFI & RMSEA & SRMR \\
\hline Takım Oluşturma & 29,58 & 4 & 0,99 & 0,99 & 0,98 & 0,96 & 0,05 & 0,03 \\
\hline Dayanışma Performansı & 33,66 & 4 & 0,99 & 0,99 & 0,97 & 0,95 & 0,06 & 0,02 \\
\hline Sosyalleşme Performansı & 12,45 & 5 & 0,99 & 0,99 & 0,99 & 0.96 & 0.06 & 0.01 \\
\hline Takım Devamlılı̆̆ı & 32,64 & 9 & 0.98 & 0.99 & 0.97 & 0.93 & 0.08 & 0.02 \\
\hline
\end{tabular}

Tablo 4 incelendiğinde takım oluşturma, dayanışma performansı, sosyalleşme performansı ve takım devamlılığı modellerine ilişkin skorların, dikkate alınan uyum iyiliği kriterleri açısından kabul edilebilir ve iyi uyum düzeyinde oldukları görülmektedir. Tüm modellere ilişkin bazı modifikasyonlar yapılmış, takım oluşturma modelinde TO1 ifadesi, takım devamlılı̆̆ında TD6 ifadesi, dayanışma performansında D2 ifadesi ve sosyalleşme performansı modelinde S1 ve S2 ifadeleri modelden çıkarıldıktan sonra geçerli modeller üretilmiştir. Takım oluşturma modeli, tüm uyum iyiliği indeksleri; (X2/df) testi, RMSEA, NNFI, CFI, GFI, AGFI ve SRMR skorları açısından iyi uyum düzeyine sahiptir. Takım performansı ile ilgili model 2 boyuttan oluşmuştur (Dayanışma performansı, Sosyalleşme performansı). Bu boyutlar içerisinde dayanışma performansı $(\mathrm{r} 2=0.77)$ boyutu sosyalleşme performansı boyutuna $(\mathrm{r} 2=0.42)$ nispetle takım performansını daha iyi düzeyde temsil etmektedir. Dayanışma performansı ve Sosyalleşme performansı modelleri $(x 2 / d f)$ testi, RMSEA skorları açısından kabul edilebilir uyum değerleri üretirken NNFI, CFI, GFI, AGFI ve SRMR uyum kriterleri açısından iyi uyum skorları üretmiştir. Benzer şekilde takım devamlılığ içerisinde en kötü uyum iyiliği değerlerine sahip olmasına rağmen ( $\mathrm{x} 2 / \mathrm{df})$ testi, RMSEA skorları açısından kabul edilebilir uyum, NNFI, CFI, GFI, AGFI ve SRMR uyum kriterleri açısından iyi uyum skorlarına sahiptir. Bununla birlikte modellere ilişkin AIC, CAIC ve ECVI değerlerinin de bağımsız model değerlerinden daha düşük oldukları tespit edilmiştir.

Doğrulayıcı faktör analizi sonrasında modeldeki değişkenler arasındaki dolaylı ve toplam ilişkiyi (üçlü ilişkiler) belirlemek ve nedensel etkiyi değerlendirmek için Path analizi gerçekleştirilmiştir. Katsayıları yorumlamak için standardize edilmiş regresyon katsayıları ve $t$ değerleri kullanılmıştır. $\mathrm{Bu}$ bağlamda araştırma modelindeki kavramsal ilişkiyi en iyi açılayan model tespit edilmeye çalışılmıştır. Analiz edilen model yapıları, uyum iyiliği ölçüt değerleri ve yol analizi bulguları ile ilgili detaylar Tablo 5 'te sunulmuştur.

Tablo 5'teki modellere ilişkin skorlar incelendiğinde, her iki modelde kabul edilebilir uyum iyiliği sonuçları üretmelerine rağmen, en iyi uyum iyiliği değerleri üreten modelin Takım Oluşturma (TAKO), Dayanışma Performansı (DAP), Takım Devamlılığı (TKD) modeli olduğu görülmektedir. Model (X2/df) testi, RMSEA, GFI ve AGFI skorları açısından kabul edilebilir uyum değerleri üretirken NNFI, CFI ve SRMR uyum kriterleri açısından oldukça iyi uyum skorları üretmiştir. Diğer taraftan Takım Oluşturma (TAKO), Sosyalleşme Performansı (SOP), Takım Devamlılığı (TKD) modeli ise tüm uyum iyiliği indeksleri açısından kabul edilebilir değerler üretmesine rağmen iyi uyum düzeyine ulaşamamıştır. Model için bazı modifikasyonlara ihtiyaç duyulmaktadır. Bu bulgular ışığında; dayanışma performansının sosyalleşme performansına kıyasla, takım oluşumu ve takım devamlılığı 
arasındaki ilişkide daha güçlü bir aracılık rolüne sahip olduğu savunulabilir. Elde edilen bu sonuç keşifsel analizlerde ulaşılan sonucu doğrulayıcı niteliktedir.

Tablo 5: Üçlü modeller-Path Analizi

\begin{tabular}{|l|l|l|l|l|l|l|l|l|}
\hline Modeller & $\chi^{\mathbf{2}}$ & df & NNFI & CFI & GFI & AGFI & RMSEA & SRMR \\
\hline TAKO $\longrightarrow$ SOP $\longrightarrow$ TKD & 517,43 & 133 & 0.96 & 0.96 & 0.87 & 0.83 & 0.08 & 0.13 \\
\hline TAKO $\rightarrow$ DAP $\longrightarrow$ TKD & 393.62 & 168 & 0.99 & 0.99 & 0.90 & 0.88 & 0.06 & 0.04 \\
\hline
\end{tabular}

Takım Oluşturma (TAKO), Dayanışma Performansı (DAP), Sosyalleşme Performansı (SOP), Takım Devamlilığı (TKD)

Diğer taraftan her iki modele ilişkin standardize edilmiş regresyon katsayıları ve $t$ değerleri dikkate alındığında TAKO-DAP-TKD modelindeki değişkenler arasındaki dolaylı ve toplam ilişkinin TAKOSOP-TKD modelindeki ilişkilere nispeten daha açıklayıcı düzeyde olduğu görülmektedir. Araştırma sonuçlarını özet olarak yansıtan modellere ilişkin $t$ değerleri aşağıda Şekil 2 ve Şekil 3 'te sunulmaktadir.

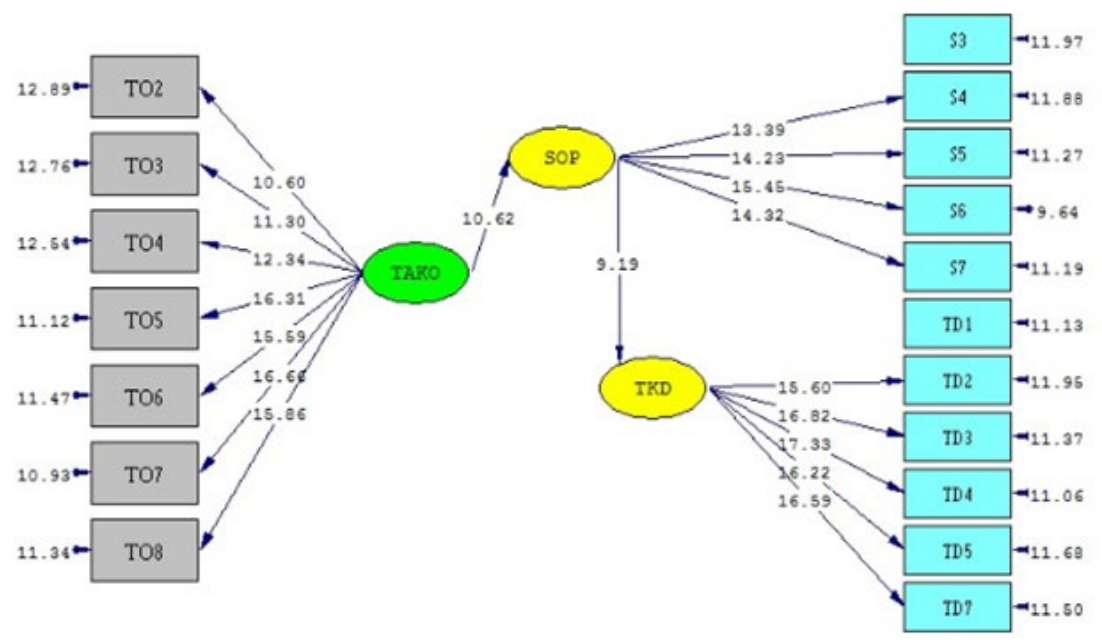

Şekil 2: TAKO-SOP-TKD modeli t değerleri

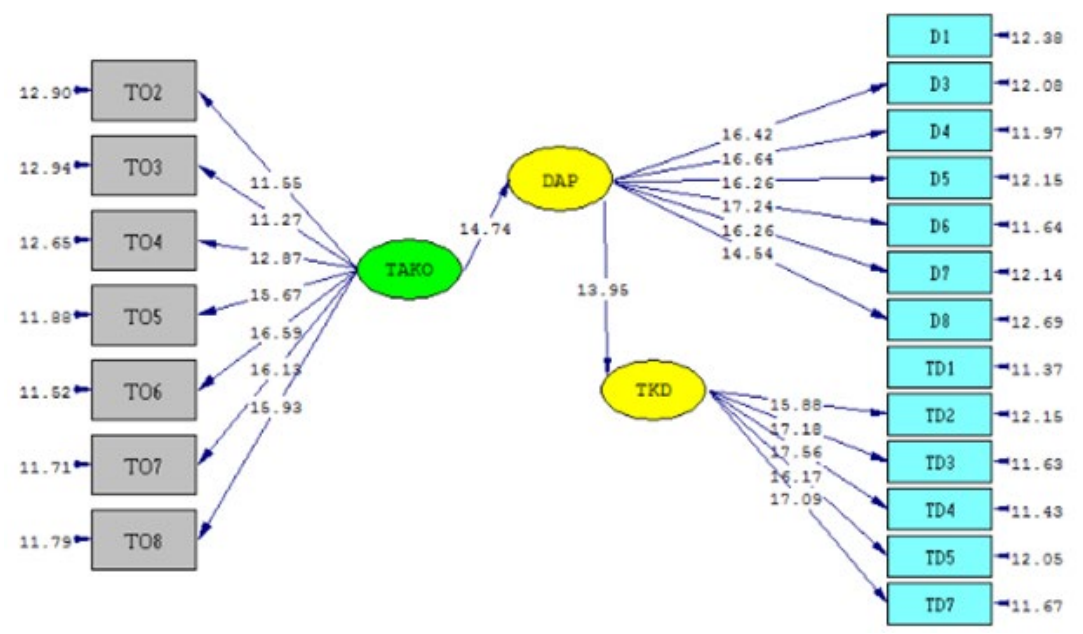

Şekil 3: TAKO-DAP-TKD modeli t değerleri

Şekil 2 ve Şekil 3 'te görülen $\mathrm{t}$ değerleri ve modellere ilişkin üretilen diğer sonuç dokümanları incelendiğinde takım oluşturma ve takım devamlılığı arasındaki dayanışma performansının daha önemli bir aracılık rolüne sahip olduğu anlaşılmaktadır. Bununla birlikte dayanışma performansına nispetle düşük olmakla beraber sosyalleşme performansının aracılık rolü de göz ardı edilmeyecek 
düzeyde anlamlı durumdadır. Dolayısıyla takım devamlılı̆g için yöneticiler tarafından her iki performans türünün de önemsenmesi gerektiği savunulabilir.

\section{Sonuç}

Takım oluşturma, takım devamlılı̆̆ı ve takım performansı arasındaki ilişkilerin incelenmesinin amaçlandığı bu araştırmanın sonuçları, çoğunlukla hizmet sektöründe faaliyet gösteren işletmelerde çalışan 25-34 yaş aralığında, erkek, lisans düzeyinde öğrenime sahip, 1-5 yıl aralığında deneyimli bireylerin bakış açılarını yansıtmaktadır.

Araştırma sonuçlarına göre takım oluşturma, hedeflerin belirlenmesi, rollerin tanımlanması, kişiler arası ilişkilerin geliştirilmesi ve problem çözme yöntemlerinin belirlenmesi ile ilgili bir süreç olarak; takım performansı, hedef ve görevlerin çok net bir şekilde belirlendiği, sonuç/kazanma odaklı rekabetçi çalışma formüllerinin üretildiği dayanışma performansı ve üyelerin birbirleriyle çok iyi anlaştığı, sırdaşlık ettiği, sıkı ilişkiler içinde olduğu ve birbirini kolladığı sosyalleşme performansından oluşan bir sonuç olarak; takım devamlılığı, uzun dönemli birlikte çalışma kapasite, kabiliyet, uyum ve motivasyondan oluşan bir olgu olarak tanımlanmıştır.

Katılımcıların üyesi oldukları takımların oluşturulma süreçlerini oldukça başarılı bulurken takımlarının devam etmesi gerektiği konusunda da olumlu yönde fikir birliğine sahiptirler. Ayrıca ait oldukları takımların dayanışma performansının oldukça iyi düzeyde sosyalleşme performansının ise nispeten düşük olduğunu düşünmektedirler. Katılımcıların özel sektör mensubu çalışan/yöneticiler olduğu göz önüne alındığında, sosyalleşme performansının düşük ancak dayanışma performansının yüksek olması çok fazla yadsınacak bir durum değildir. Çünkü genelde özel sektördeki takım yapılanmaları için önemli olan, kişilerarası ilişkiler ya da dostluktan çok, ortak ilgi alanları doğrultusundaki hedeflere ulaşılmasıdır.

Araştırma kapsamında çalışanların takım oluşumu sürecine ait görüşleri dikkate alındığında en önem verdikleri konuların, takımın kurallarının ve hedeflerinin açıkça belirtilmesi olduğu görülmektedir. Konuya ilişkin literatür incelendiğinde benzer sonuçların elde edildiği çalışmalarla karşılaşılmıştır (Örneğin: Aga vd., 2016: 807; Wildmeyer ve Ducharme, 1997: 107; Locke ve Latham, 2002: 706-707). Şöyle ki takım oluşturma sürecinde takım kuralları ve rollerin açıkça belirtilmesi görevlerin daha iyi anlaşılmasını (Salas vd., 1999: 314) ve çıabilecek anlaşmazlıkları önlemeyi sağlayarak takım etkinliğini artırmaktadır (Lacerenza vd., 2018: 524). Katılımcıların takım performansıyla ilgili görüşlerinde ise takımın hedeflere ulaşması ve üyelerin kazanma isteği ile ilgili dayanışma yönlü eğilim dikkati çekmektedir. Literatürde bu konular takım performansının değerlendirilmesi konusunda ön plana çıkan hususlarda yer aldığı için sonuçların uyumundan bahsedilebilir. Bu kapsamda takımın ortak hedefleri hızlı ve etkili bir şekilde gerçekleştirme becerisi (Jones ve Goffee, 1996) ve üyelerin organizasyonun hedefine ulaşmak için fazladan çaba gösterme isteği (Moskovich, 2016: 358) etkili bir dayanışmanın göstergesi olarak değerlendirilmektedir. Takım devamlılığ1 noktasında ise araştırmaya katılanlar, takımların olası problemleri çözebilme ve birlikte çalışabilme kabiliyetine daha fazla vurgu yapmaktadırlar. Literatürde de takımın yaşamını sürdürebilmesi için takım içi uyumu artırma, problemlere etkili ve zamanında çözüm üretebilme ve birlikte çalışmaya devam etme kapasitesini artıran koşulları ve süreçleri keşfetme (Dimas vd., 2017: 561; Maynard, 2015: 654) gibi koşullar takım devamlılığı için gerekli koşullar olarak tartışılmaktadır. Dolayısıyla elde edilen sonuçların literatürle önemli ölçüde örtüştüğü söylenebilir.

Değişkenler arasındaki doğrudan (ikili) ilişki/etkilere yönelik genel anlamda bir değerlendirme yapılacak olursa takım oluşturma, takım performansı ve takım devamlılı̆̆ı arasında yüksek ve orta düzeyde pozitif yönlü ilişkiler olduğu söylenebilir. Spesifik anlamda bir değerlendirme yapıldığında ise ilk olarak takım oluşturma ile takım devamlılı̆̆ arasında yüksek düzeyli, pozitif yönlü ve anlamlı bir ilişki olduğu ortaya çıkmıştır. Bu bulguya göre, paylaşılacak ortak bir hedef uğruna sistematik bir analiz neticesinde oluşturulacak olan takım, üyelerinin uyum sağlama ve birlikte performans sürdürme becerilerini arttırarak devamlılık düzeylerini pozitif yönde etkileyecektir. Literatürde elde edilen bu sonuca oldukça benzer araştırma sonuçlarına rastlanmıştır. Örneğin Aube ve Rousseau (2011), oluşturulan takıma ait üye davranış biçimlerinin takım devamlılığı etkilediği sonucuna ulaşmıştır. Benzer şekilde Ammeter ve Dukerich (2002: 10) de takım oluşturmanın etkinliğinin, takım devamlılığına katkı sağladığını belirtmektedir. Takım oluşturma sürecinin başlıca amaçları arasında; ekip üyeleri arasındaki iletişim geliştirilmesi, üretkenlik düzeyinin artırılması, açık çalışma hedefleri ve iş birliğine dayalı problem çözme ortamının sağlanması vardır (Fapohunda, 2013: 4). Bu amaçlar doğrultusunda başarılı bir şekilde oluşturulan takımların, devamlılık sağlama konusunda daha başarılı olabilecekleri söylenebilir. İkinci olarak takım oluşturma ile takım performansı alt boyutlarından dayanışma performansı arasında pozitif yönlü yüksek düzeyde anlamlı bir ilişki 
bulunmuştur. Bu bulgu; takımın hedeflerinin belirli olmasının, üyeleri arasında olumlu ilişkilerin, rol belirginliğinin ve problem çözücü davranışların yüksek düzeyde olmasının, takımın dayanışma performansını artırıcı nitelikte olduğunu göstermektedir. Takım oluşturmanın ana amacının ortak iş hedefine ulaşma konusunda duygusal değil profesyonel iş ilişkilerini desteklemek olduğu göz önünde bulundurulduğunda, takım oluşturma ile dayanışma performansı arasında böyle yüksek düzeyde bir ilişki oldukça makul sayılabilir. Nitekim elde edilen bu sonuç literatürle paralellik göstermektedir. Örneğin Salas (1999) tarafından yürütülen araştırmada, takım oluşturma süreçlerinin takım performansı üzerinde düşük ama pozitif yönlü bir etkiye sahip olduğu, özellikle rol netleştirme bileşeniyle ne kadar çok ilgilenilirse performans üzerindeki etkisinin o kadar büyük olacağ1 savunulmaktadır. Ammeter ve Dukerich (2002: 9-10) çı̆̆ır açan performans elde eden proje takımları, güçlü proje liderliği ve doğru seçilmiş takım üyeleri ile ilgili çalışmalarında benzer sonuçlar elde etmişlerdir. Mullen ve Coper (1995) takım üyelerinin zevk alma eğiliminde oldukları bir görevi tamamlamalarının, onları performans noktasında daha fazla çaba ve dayanışmaya yönlendireceğini tespit etmiştir. Takım oluşturmanın özellikle hedef belirleme, rol tanımlama ve problem çözücü davranışlar gibi süreçleri düşünüldüğünde, bu özelliklerin dayanışma performansının; ilişkilerin paylaşılan ortak görevler, hedefler veya karşılıklı çıkarlarla kurulması (Ortiz ve CruzFreire, 2012: 20) enerji, yoğunlaşma ve odaklanmayı takım olarak gerçekleştirme (Pinto vd., 2011: 380) gibi özelliklerine pozitif yönlü anlamlı bir etkide bulunması beklenen bir durumdur.Diğer taraftan dayanışma performansı kadar yüksek düzeyde olmamakla birlikte takım oluşturma ile sosyal performans arasında da orta düzeyde, anlamlı ve pozitif bir ilişki tespit edilmiştir. Takım oluşturmanın özellikle üyeler arasındaki kişisel ilişkilerin geliştirilmesi yönlü süreçleri, bu ilişkiyi güçlendirici niteliktedir. Yine araştırmanın gerçekleştirildiği örneklem grubunun kültürel özellikleri düşünüldüğünde, bu ilişkinin daha yüksek düzeyde olması beklenmektedir. Literatür incelendiğinde elde edilen sonuçları destekler nitelikte çeşitli çalışmalara rastlanmaktadır. Şöyle ki takım üyeleri arasındaki ilişkilerin gelişmesinin daha etkili kararların alınmasını sağlayacağı (Liebowtiz ve De Meuse, 1982: 7), iletişimin artması ve kişilerarası ilişkilerin düzenlenmesinin takım etkinliğini ve üretkenliğini artıracağı (Argyris, 1962: 712), takım etkinliğinin birlikte çalışmayı, disiplinli olmayı, birbiriyle iletişim kurmayı ve sosyalleşmeyi netice vereceği (Altaftazani vd., 2020: 192) savunulmaktadır.Son olarak değişkenler arasındaki doğrudan ilişkiler bağlamında takım performansı boyutlarından dayanışma performansı ile takım devamlılı̆̆ arasında yüksek düzeyde, sosyalleşme performansı ile takım devamlılı̆̆ı arasında orta düzeyde pozitif yönlü bir ilişki bulunmuştur. Elde edilen her iki sonuçta hem pratik geçerlilik hem de teorik kurgu anlamında kolaylikla kabul edilebilir durumdadır. Çünkü performansı yüksek takımlar genelde sosyal ilişkilerinin ve dayanışma motivasyonunun üst düzey olduğu takımlardır. Takım devamlılığının; birlikte çalışmaya devam etmek için gerekli motivasyon ve kabiliyete, sorun çözme becerisine, engeller karşısında direnmek için gereken olanaklara sahip olma ve meydana gelen değişikliklere kolayca uyum sağlama gibi özellikleri düşünüldüğünde bu sonuç daha anlamlı hale gelmektedir. Şöyle ki takım üyeleri arasındaki dayanışma, bireysel ve organizasyonel anlamda birçok olumlu duygularla sonuçlanmaktadır (Sanders ve Van Emmerik, 2004: 359). Üyelerin olumlu deneyimler yaşaması, takım uyumunu, etkinliğini, performansını ve yeniden birlikte çalışma isteğini etkilemektedir (Maynard, 2015: 654). Aynı şekilde takım üyelerinin sosyalleşmesi, bireyler için kendilerini geliştirmeye ve iş tatmine yardımcı olurken (Feldman, 1981: 310), organizasyonlar için çalışanların entegrasyon sürecinin kısalmasına ve örgütsel bağlılığının artmasına yardımcı olabilmektedir (Liao vd., 2016: 94). Yine sosyalleşme genelde bilgi paylaşımını açık hale getirmenin yanı sıra çalışanların takım arkadaşlarını yarı yolda bırakma davranışını da engellemektedir (Goffee ve Jones, 1998: 47-49). Dolayısıyla takım içerisinde dostluk ilişkisi kuran çalışanların birlikte çalışma motivasyonu artacağı ve bu durumun takım devamlılığını pozitif yönde etkileyeceği söylenebilir. Aynı şekilde dayanışma performansı, takım üyelerinin müşterek ilgi alanlarına, ortak görevlerine, açıç̧a kavranmış paylaşılan ortak hedeflerine, engellere ortak direnç gösterme, içsel uyum sağlama ve sorun çözme becerisine dayandığı için takım devamlılığını sağlayan koşullarla pozitif yönlü bir etkileşim sağlayabilecektir.

Diğer taraftan araştırmanın temel sorunsalını çözmeye yönelik gerçekleştirilen aracılık testi sonucunda genel anlamda takım performansının, takım oluşturma ve takım devamlılığı arasındaki ilişkide kısmi aracılık etkisine sahip olduğu belirlenmiştir. Daha spesifik ilişkiler bağlamında takım performansının alt boyutlarının aracılık rolüne ilişkin gerçekleştirilen analiz sonucunda ise gerek dayanışma performansı gerekse sosyalleşme performansının kısmi aracılık rolüne sahip oldukları tespit edilmiştir. Benzer sonuçlara, araştırma bulgularını daha güçlü analizlerle sınamak ve yapısal geçerliliği test etmek için gerçekleştirilen doğrulayıcı karakterli (path analizi) analizlerde de rastlanmıştır. Bu bulgulara göre başarılı bir şekilde takımın oluşturulması halinde, takım üyelerinin devamlılık konusunda sorun yaşamayacağı ancak takım üyeleri arasındaki duygusal ilişki derecesinin bir göstergesi olan sosyal performansın yeterli seviyede olmaması halinde, bir müddet sonra takımın 
devamlılı̆̆ tartışma konusu olabilir. Aynı şekilde, organizasyonun hedefine ulaşmak için fazladan çaba gösterme isteğinden kaynaklanan, ortak hedefleri hızlı ve etkili bir şekilde gerçekleştirme becerisinin bir ölçüsü olarak dayanışma performansının yeterli olmaması durumunda takımlar uzun vadede dağılma tehlikesiyle karşı karşıya kalabilir. Buradan hareketle iyi oluşturulan takımların ancak iyi bir dayanışma ve sosyalleşme performansı gösterdikleri takdirde takım devamlılığını sürdürebileceği söylenebilir. Bununla birlikte sosyalleşme performansına nispetle dayanışma performansının daha güçlü bir aracılık rolüne sahip olduğu ortaya çıkmıştır. Konuya ilişkin literatür incelendiğinde Balkundi ve Harrison (2006: 60-61) tarafından yürütülen araştırmada da paralel doğrultuda, sosyal performansın ve dayanışma performansının ayrı ayrı takım devamlılı̆̆ını pozitif yönde etkilediğini fakat takım devamlılı̆̆ını sağlamada dayanışma performansının sosyal performanstan daha önemli nitelikte olduğu sonucuna ulaşıldığ 1 belirlenmiştir. Sosyalleşme performansının nispeten düşük bir etkiye sahip olmasının bazı nedenleri literatürde tartışılmaktadır. Özellikle performansı özelinde düşünüldüğünde sosyalleşme performansının her koşulda takım sonuç ve devamlılı̆̆ına pozitif yönlü yansıyacağı konusunda bazı endişeler bulunmaktadır. Goffee ve Jones (1998) konuya ilişkin olumsuz sosyalleşme (sosyalleşmenin karanlık yüzü) durumunu gündeme getirmektedir. Yani bazı organizasyonlarda sosyalleşme düzeyi çok yüksek olmasına rağmen sonuç ve performansa dönük çaba ve gayret istenilen düzeyde gerçekleşmemekte ve bu durum zamanla gruplarda dağılma yönlü eğilimlere neden olabilmektedir.

Bulgular üzerinde buraya kadar yapılan tartışmalara göre oluşturulan takımlarının sonuç odaklı performans sergilemeksizin yaşamlarına devam etmeleri çok mümkün görünmemektedir. Bununla birlikte dayanışma performansına nispetle düşük olmakla beraber sosyalleşme performansının aracılık rolü de göz ardı edilmeyecek düzeyde anlamlı durumdadır. Dolayısıyla takım devamlılığı için takım üyelerinin sosyal ilişki biçim ve seviyelerinin de önemli olduğu savunulabilir. Bu kapsamda takım performansı olarak sadece dayanışma performansının önemsenmesi sonuç alıcı formülasyonların üretilmesine ciddi katkı sağlarken takım içi samimiyet, bağlılık, sadakat gibi sosyal yönlerin zayıf kalmasına neden olabilecektir. Yine sadece sosyal performansa önem verilmesi takım içi samimiyet ve bağlılığı artırırken sonuç alıcı çalışmalar konusunda bazı istismar durumlarının oluşmasını doğurabilecektir. Dolayısıyla takım devamlılığı için yöneticiler tarafından her iki performans türünün de önemsenmesi gerekmektedir.

İşletmelerin dinamik olarak değişen, belirsizliğin hâkim olduğu bir ortamda bulunmaları ve artan yenilik ihtiyacı nedeniyle takım bazlı organizasyon yapılarını başarılı şekilde inşa etmeleri gerekmektedir. Uyumlu bir takımın oluşturulması, takım içerisinde sosyal performans ve dayanışma performansının gerçekleşmesi ile pekiştirilerek, takımın uzun vadede birlikte çalışma isteğini güçlendirmektedir. Bu araştırmanın sonuçları, sektörde yer alan takım bazlı organizasyonların başarısı için yol gösterici bir çalışma olarak literatüre ve uygulayıcılara katkı sağlamaktadır.

Son olarak yürütülen araştırma metodolojik anlamda bazı sınırlılıklara sahiptir. Örneğin araştırma çeşitli hizmet alanlarında faaliyet gösteren işletme ve kurum çalışanları ile gerçekleştirildiği için homojen bir örneklem üzerinde gerçekleştirilmemiştir. Daha homojen örneklemler üzerinde çalışılması daha farklı sonuçlar ortay çıarabilecektir. Aynı zamanda örneklem sayısı her ne kadar yeterli sayıda olsa da gerçekleştirilen analizlerden daha güçlü sonuçlar elde edilmesi için daha büyük örneklem gruplarıyla çalışmaya ihtiyaç vardır. Araştırma sonuçlarının genellenebilirliği noktasında bu durum kritik bir öneme sahiptir.

\section{Hakem Değerlendirmesi / Peer-review:}

Dış bağımsız

Externally peer-reviewed

\section{Çıkar Çatışması / Conflict of interests:}

Yazar(lar) çıkar çatışması bildirmemiştir.

The author(s) has (have) no conflict of interest to declare.

\section{Finansal Destek / Grant Support:}

Yazar(lar) bu çalışma için finansal destek almadığını beyan etmiştir.

The author(s) declared that this study has received no financial support. 


\section{Etik Kurul Onayı / Ethics Committee Approval:}

Bu çalışma için etik kurul onayı, Düzce Üniversitesi, Bilimsel Araştırma ve Yayın Etik Kurulundan 09/04/2021 tarihli 2021/109 sayılı karar ile alınmıştır.

Ethics committee approval was received for this study from Düzce University, Scientific Research and Publication Ethics Committee on 09/04/2021 and 2021/109 document number.

\section{Yazar Katkıları / Author Contributions:}

Fikir/Kavram/Tasarım - Idea/Concept/ Design: Y.E.T. Veri Toplama ve/veya İşleme - Data Collection and/or Processing: M.B., N.K., M.Ö. Analiz ve/veya Yorum - Analysis and/or Interpretation: Y.E.T. Kaynak Taramas1 - Literature Review: M.B., N.K., M.Ö. Makalenin Yazımı - Writing the Article: Y.E.T., M.B., N.K., M.Ö. Eleştirel İnceleme - Critical Review: Y.E.T., Onay - Approval: Y.E.T., M.B., N.K., M.Ö.

\section{Kaynakça / References}

Aga, D. A., Noorderhaven, N., ve Vallejo, B. (2016), “Transformational leadership and project success: The mediating role of team-building", International Journal of Project Management, Vol.34, No.5, 806-818.

Alliger, G.M., Cerasoli, C.P., Tannenbaum, S.I. ve Vessey, W.B. (2015), "Team resilience: How teams flourish under pressure", Organizational Dynamics, Vol.44, No.3, 176-184.

Altaftazani, D. H., Rahayu, G. D. S., ve Kelana, J. B. (2020), "An Analysis of Basic Interaction, Communication, Team Building, and Problem-Solving Skills of Primary School Students in Marching Band Activities", In Elementary School Forum, Vol.7, No.2, 184-197.

Ammeter, A.P. ve Dukerich, J. M. (2002), "Leadership, team building, and team member characteristics in high performance Project teams", Engineering Management Journal, Vol.14, No.4, 3-10.

Anant, H.S. (2015), "A Study of the Impact of Openness and Trust on the Quality of Interpersonal Relations within Organizations", International Journal of Recent Advances in Organizational Behaviour and Decision Sciences (IJRAOB) An Online International Research Journal, Vol.1, No.3, 429-451.

Argyris, C. (1962), "Interpersonal competence and organizational effectiveness", American Sociological Review, Vol.27, No.5, 712-713.

Aubé, C. ve Rousseau, V. (2005), “Team goal commitment and team effectiveness: The role of task interdependence and supportive behaviors", Group Dynamics: Theory, Research, and Practice, Vol.9, No.3, 189-204.

Balkundi, P. ve Harrison, D.A. (2006), “Ties, Leaders, And Time In Teams: Strong Inference About Network Structure's Effects On Team Viability And Performance", Academy of Management Journal, Vol.49, No.1, 49-68.

Bartlett, A. B., Probber, J., ve Mohammed, S. (1999), "The effect of team-building on team process and performance", Journal of Hospitality \& Tourism Research, Vol.23, No.3, 299-311.

Beer, M. (1976), "The technology of organization development", Handbook of industrial and organizational psychology, 937-994.

Bell, S. T. ve Marentette, B. J. (2011), “Team viability for long-term and on going organizational teams", Organizational Psychology Review, Vol.1, No.4, 275-292.

Bell, S.T. ve Marentette, B.J. (2011), "Team viability for long-term and ongoing organizational teams", Organizational Psychology Review, Vol.1, No.4, 275-292.

Bryman, A., ve Cramer, D. (2001), Quantitative data analysis with SPSS Release 10 for Windows, New York.

Buller, P. F. (1986), “The team building-task performance relation: Some conceptual and methodological refinements", Group \& Organization Studies, Vol.11, No.3, 147-168.

Buller, P. F., ve Bell Jr, C. H. (1986), "Effects of team building and goal setting on productivity: A field experiment", Academy of Management Journal, Vol.29, No.2, 305-328. 
Büyüköztürk, Ş. (2002), "Faktöranalizi: Temel kavramlar ve ölçek geliştirmede kullanımı”, Kuram ve Uygulamada Egitim Yönetimi Dergisi, Cilt.8, Sayı.4, 470-483.

Büyüköztürk, Ş. (2006), Sosyal Bilimler İçin Veri Analizi El Kitabı, Pegem A Yayıncılık, Ankara.

Ciasullo, M. V., Cosimato, S., Gaeta, M. and Palumbo, R. (2017), “Comparing two approaches to team building: a performance measurement evaluation", Team Performance Management, Vol.23, No.7/8, 333-351.

Cohen, S.G. ve Bailey, D.E. (1997), “What makes teams work: Group effectiveness research from shop floor to the executive suite", Journal of Management, Vol.23, No.3, 239-290.

Cooperstein, J.N. (2017), "Initial Development of a Team Viability Measure”, College of Science and Health Theses and Dissertations, 202.

Costa, P.L., Passos, A.M. ve Barata, M.C. (2015), "Multilevel influences of team viability perceptions", Team Performance Management, Vol.21, No.2, 19-36.

De Meuse, K. P., ve Liebowitz, S. J. (1981), “An empirical analysis of team-building research”, Group \& Organization Studies, Vol.6, No.3, 357-378.

Dimas I.D., Rocha H., Rebelo T. ve Lourenço P.R. (2017), “A Neural Network Model for Team Viability", Computational Science and Its Applications - ICCSA 2017: 560-573.

Driskell, J. E. (1992), “Collective Behavior and Team Performance”, Human Factors, 1992, Vol.34, No.3, 277-288.

Dyer Jr, W. G. (2015), “Team building”, Wiley Encyclopedia of Management, 1-2.

Dyer, W. G. (1977), Team building: Issues and alternatives, Reading, MA: Addison-Wesley.

Ergün, E., ve Eyisoy, M. E. (2018), “Takım Çalışması Özelliklerinin Takım Performansına Etkisi Üzerine Bir Araştırma", Business \& Management Studies: An International Journal, Vol.6, No.4, 1455-1475.

Eys, M. A., ve Carron, A. V. (2001), "Role ambiguity, task cohesion, and task self-efficacy", Small group research, Vol.32, No.3, 356-373.

Fapohunda, T. M. (2013), "Towards effective team building in the workplace", International Journal of Education and Research, Vol.1, No.4, 1-12.

Feldman, D. C. (1981), "The multiple socialization of organization members", Academy of Management Review, Vol.6, No.2, 309-318.

Galbraith, J., Lawler, E. ve Dimon, J. (2007), "Organization structure and management systems", The Tools Of Strategy Analysis, 169-200.

Goffee, R. ve Jones, G. (1998), Kurum Kültürü: Kuruluşunuzun Kurumsal Kültürünün İşiniz Üzerindeki Yıkıcı ve Yapıcı Etkileri, Kapital Medya Hizmetleri A.Ş., Ankara.

Gorman, J. C., Cooke, N. J., ve Amazeen, P. G. (2010), “Training adaptive teams", Human Factors: The Journal of the Human Factors and Ergonomics Society, Vol.52, 295-307.

Hassan, S. (2013), “The Importance of Role Clarification in Workgroups: Effects on Perceived Role Clarity, Work Satisfaction, and Turnover Rates", Public Administration Review, Vol.73, No.5, 716725.

Hitt, M.A., Keats, B.W. ve DeMarie, S.M. (1998), "Navigating in the new competitive landscape: Building strategic flexibility and competitive advantage in the 21st century", Academy of Management Executive, Vol.12, No.4, 22-42.

Hooper, D., Coughlan, J. ve Mullen, M. (2008), "Structural Equation Modelling: Guidelines for Determining Model Fit", Electronic Journal of Business Research Methods, Vol. 6, No.1, 53-60.

Jackson, S.E., Chuang, C., Harden, E.E. ve Jiang, Y. (2006), “Toward Developing Human Resource Management Systems for Knowledge-Intensive Teamwork", Research in Personnel and Human Resources Management, Vol.25, 27-70.

Jeczmien, A.S., Chomatowska, B., Janiak-Rejno, I. ve Żarczyńska-Dobiesz, A. (2019), “Making team viably - a challenge for contemporary companies", Selected problems of managing organization development in industry 4.0 . 
Jewczyn, N. B. (2010), “Assessing mechanistic and organic organizational structures: Measuring organizational uncertainty and determining an organization's proper structure", Journal of Business Management and Entrepreneurship, Vol.1, No.6, 1-12.

Jones, G., ve Goffee, R. (1996), "What Holds the Modern Company Together?", Harward Business Review, https://hbr.org/1996/11/what-holds-the-modern-company-together (Erişim Tarihi: 14.03.2021).

Jordan, P.j., ve Troth, A.C. (2004), “Managing Emotions During Team Problem Solving: Emotional Intelligence and Conflict Resolution", Human Performance, Vol.17, No.2, 195-218.

Kahn, R. L., Wolfe, D. M., Quinn, R. P., Snoek, J. D., ve Rosenthal, R. A. (1964), “Organizational stress: Studies in role conflict and ambiguity", American Sociological Review, Vol.30, No.4, 620.

Kalaycı, Ş. (2009), SPSS Uygulamalı Çok Değişkenli İstatistik Teknikleri, Ankara: Asil Yayın Dağıtım.

Karagöz, Y. (2014), SPSS 21.1 Uygulamalı Biyoistatistik, Ankara: Nobel Yayınevi.

Klein, C., Diaz Granados, D., Salas, E., Le, H., Burke, C. S., Lyons, R., ve Goodwin, G. F. (2009), “Does team building work?", Small Group Research, Vol.40, No.2, 181-222.

Lacerenza, C. N., Marlow, S. L., Tannenbaum, S. I., ve Salas, E. (2018), “Team development interventions: Evidence-based approaches for improving teamwork", American Psychologist, Vol.73, No.4, 517.

Liao, J., Huang, M. ve Xiao, B. (2016), "Promoting continual member participation in firm-hosted online brand communities: An organizational socialization approach", Journal of Business Research, Vol.71, 92-101.

Liebowitz, S. J., ve De Meuse, K. P. (1982), “The application of team building", Human Relations, Vol.35, No.1, 1-18.

Lin, T. C., Chen, C. M., Hsu, J. S. C., ve Fu, T. W. (2015), “The impact of team knowledge on problem solving competence in information systems development team", International Journal of Project Management, Vol.33, No.8, 1692-1703.

Locke, E. A., ve Latham, G. P. (2002), "Building a practically useful theory of goal setting and task motivation: A 35-year odyssey", American psychologist, Vol.57, No.9, 705.

Locke, E. A., Shaw, K. N., Saari, L. M. ve Latham, G. P. (1981), “Goal setting and task performance: 1969-1980", Psychological Bulletin, Vol.90, 125-152.

Lyubovnikova, J., Legood, A., Turner, N. ve Mamakouka, A. (2015), “How authentic leadership influences team performance: the mediating role of team reflexivity", Journal of Business Ethics, Vol.141, No.1, 59-70.

Maruyama, G. M. (1998), Basics of Structural Equation Modeling. Thousand Oaks, CA: Sage Publications.

Maynard, M.T., Kennedy, D. M. ve Sommer, A. (2015), “Team adaptation: A fifteen-year synthesis (1998-2013) and framework for how this literature needs to "adapt" going forward", European Journal of Work and Organizational Psychology, Vol.24, No.5, 652-677.

McDonald, R. P., ve Ho, M. H. R. (2002), "Principles and practice in reporting structural equation analyses", Psychological Methods, Vol. 7, No.1, 64-82.

McGrath, J.E. (1962), "The influence of positive interpersonal relations on adjustment and effectiveness in rifle teams", The Journal of Abnormal and Social Psychology, Vol.65, No.6, 365-375.

Miller, K. I., ve Monge, P. R. (1986), "Participation, satisfaction, and productivity: A meta-analytic review", The Academy of Management Journal, Vol.29, No.4, 727-753.

Miles, J., ve Shevlin, M. (2007), “A time and a place for incremental fit indices", Personality and individual differences, Vol. 42, No.5, 869-874.

Moskovich, Y. (2016), "Loss of organizational solidarity in three kibbutz factories", International Journal of Sociology and Social Policy, Vol.36, No.5/6, 358-378.

Mowday, R. T., Steers, R. M.ve Porter, L.W. (1979), "The measurement of organizational commitment", Journal of Vocational Behavior, Vol.14: 224-247. 
Mullen, B. ve Copper, C. (1994), “The relation between group cohesiveness and performance: An integration", Psychological Bulletin, Vol.115, No.2, 210.

Ortiz, D. A. ve Freire Cruz, T. (2012), "Performance improvement in teamwork as a function of the cultural dimensions: solidarity and sociability in the organizational behavior", Revista Científica Electrónica de Ciencias Gerenciales / Scientific e-journal of Management Sciences, Vol.21, No.7, 18-29.

Pallant, J. (2007), SPSS Survival Manual, McGraw-Hill Education, Berkshire, England.

Panaccio, A., ve Vandenberghe, C. (2011), “The Relationships of Role Clarity and Organization-Based Self-Esteem to Commitment to Supervisors and Organizations and Turnover Intentions", Journal of Applied Social Psychology, Vol.41, No.6, 1455-1485.

Pinto, L. H., Cabral-Cardoso, C., ve WertherJr. W. B. (2011), “Why solidarity matters (and sociability doesn't): The effects of perceived organizational culture on expatriation adjustment", Thunderbird International Business Review, Vol.53, No.3, 377-389.

PreacherK. J., ve Leonardelli, G. J. (2021), “Calculation for the Sobel test: An interactive calculation tool for mediation tests", http:/ / quantpsy.org/sobel/sobel.htm, (Erişim Tarihi: 08.05.2021).

Puente-Palacios, K., Carmo Fernandes Martins, M. ve Palumbo, S. (2016), “Team performance: Evidence for validity of a measure", Psico-USF, Bragança Paulista, Vol.21, No.3, 513-525.

Purtul, T. (2019), "Antecedents of better performing teams: Test of perceived team job crafting model", Mater Thesis, The Graduate School Of Social Sciences Of Middle East Technical University, Ankara.

Salas, E., Rozell, D., Mullen, B., ve Driskell, J. E. (1999), "The effect of team building on performance: An integration", Small group research, Vol.30, No.3, 309-329.

Sanders, K. ve Van Emmerik, H. (2004), “Does modern organization and governance threat solidarity?", Journal of Management and Governance, Vol.8, 351-372.

Senécal, J., Loughead, T. M., ve Bloom, G. A. (2008), “A season-long team-building intervention: Examining the effect of team goal setting on cohesion", Journal of Sport and Exercise Psychology, Vol.30, No.2, 186-199.

Senior, B. ve Swailes, S. (2004), “The dimensions of management team performance: a repertory grid study", International Journal of Productivity and Performance Management, Vol.53, No.4, 317-333.

Shuffler, M. L., Diaz Granados, D., ve Salas, E. (2011), “There's a science for that: Team development interventions in organizations", Current Directions in Psychological Science, Vol.20, No.6, 365-372.

Sundstrom, E., Meuse, K. ve Futrell, D. (1990), "Work Teams Applications and Effectiveness", American Psychological Association, Vol.45, No.2, 120-133.

Svyantek, D. J., Goodman, S. A., Benz, L. L., ve Gard, J. A. (1999), “The relationship between organizational characteristics and team building success", Journal of Business and Psychology, Vol.14, No.2, 265-283.

Tannenbaum, S. I., Beard, R. L., ve Salas, E. (1992), “Team building and its influence on team effectiveness: An examination of conceptual and empirical developments", In Advances in psychology, Vol.82, 117-153.

Van Maanen, J., ve Schein, E. H. (1979), “Toward a theory of organizational socialization", In B. M. Staw (Ed.), Research in Organizational Behaviour, Vol.1, 209-264.

Widmeyer, W. N., ve Ducharme, K. (1997), "Team building through team goal setting”, Journal of Applied Sport Psychology, Vol.9, No.1, 97-113.

Yammarino, J., Atwater, L. E. ve Spangler, W. D. (2004), "Transformational leadership and team performance", Journal of Organizational Change Management, Vol.17, No.2, 177-193.

Yukl, G., Gordon, A. ve Taber, T. (2002), “A Hierarchical Taxonomy of Leadership Behavior: Integrating Half a Century of Leadership Research", Journal of Leadership and Organization Studies, Vol.9, No.1, 15-32.

Zigon, J. (1999), How to Measure Team Performance, Zigon Performance Group, Media, PA, Philadelphia. 


\section{Ek 1: Ölçek Maddeleri}

\begin{tabular}{|c|}
\hline Takım Devamlılığı \\
\hline - Birlikte çalışmaya devam etmek için gerekli motivasyon \\
\hline - Uzun vadeli başarı kapasitesi \\
\hline - $\quad$ Birlikte çalışma kabiliyeti \\
\hline - Engeller karşısında direnme olanakları \\
\hline - Sorun çözme başarısı \\
\hline - Sürekli başarn için kendini iyi konumlandırma* \\
\hline - Meydana gelen değişikliklere kolayca uyum sağlama \\
\hline Takım Oluşturma \\
\hline - Sorunları çözmek için eylem planlarının uygulanmasında görevlendirme* \\
\hline - Takım kurallarının her üye tarafından kolayca bilinebilmesi \\
\hline - Üyeleri problemleri belirleme sürecine dâhil etme \\
\hline - $\quad$ Rol beklentilerini net olarak belirleme \\
\hline - Temel hedefleri ayrıntılı şekilde açıklama \\
\hline - Üyeleri hedeflerin gerçekleştirilmesine yönelik eylem planlamasına dâhil etme \\
\hline - Kişisel ilişkileri dürüstçe tartışabilme \\
\hline - Yakından tanışmaya teşvik etme \\
\hline Takım Performansı \\
\hline Dayanışma Performansı \\
\hline - Hedefleri tutturmak için çok ciddi şekilde çalışma \\
\hline - Kazanmayı gönülden arzulama* \\
\hline - Rakipleri yenmeye çok azimli olma \\
\hline - İşle ilgili talimatlara tam uyum \\
\hline - İş hedefini çok iyi bilme \\
\hline - Projeleri çoğunlukla başarılı bir şekilde tamamlama \\
\hline - Sorunların kritik noktalarını çok iyi belirleye bilme \\
\hline - Kimin görevinin nerede başlayıp nerede bittiğinin gayet belirgin olması \\
\hline Sosyalleşme Performansı \\
\hline - Kişisel konularda çok sırdaşlık \\
\hline - Birbirlerinin aileleri hakkında pek çok şey bilme* \\
\hline - İşten ayrılanlarla ilişkiyi hep sıcak tutma \\
\hline - İş dışında da çok sık bir araya gelme \\
\hline - $\quad$ Birbirlerini gerçekten sevdiklerine olan inanç \\
\hline - $\quad$ Birbirleriyle çok iyi anlaşma ve nadiren tartışma \\
\hline - Her zaman birbirlerini kollama \\
\hline
\end{tabular}

